\title{
6. Recent Changes Moving Hungary Away from the European Social Model
}

\author{
Ágota Scharle and Dorottya Szikra
}

\section{INTRODUCTION}

Hungary inherited a fairly comprehensive welfare model from the Socialist regime, which was further consolidated at the moment of entering the European Union and the adoption of the EU acquis. However, this system has been challenged by a number of recent reforms.

This chapter describes in particular the radical transformation of the Hungarian welfare system over the past three years. Although cuts in welfare provisions have occurred repeatedly in response to fiscal crises during the past twenty years, we shall argue that the recent changes are much more fundamental and are determined by different, more political motivations. The weakening of workers' rights and consultative institutions, the severe cuts in social protection for the unemployed, the abolition of early pensions, the renationalisation of the private pension pillar and the neglect of equal opportunities policies have substantially weakened the originally relatively generous welfare system in Hungary. This has led to a further polarization of society, deepening poverty, growing insecurity and a rise in emigration.

Our main aim is to assess recent changes affecting the elements of the European Social Model in Hungary. Wherever possible, we rely on references to existing accounts of these changes. This allows us to explore in more detail the area of unemployment provisions, with regard to which recent reforms have been the most controversial and discordant with the European Social Model. We describe repeated cuts in unemployment benefits and social assistance, coupled with the expansion of the public works programme and a reduction of other active labour market measures since 2010. We show that this has increased the risk of poverty among the unemployed, contributed to a rise in persistent poverty and deepened structural unemployment, which may prolong the process of economic recovery.

The next two sections set the scene by giving a broad-brush description of the Socialist welfare regime and a brief account of the main changes during and after the transition to a market economy. Section 3 outlines changes between 2000 and 2013, focusing on three broad areas of the European Social Model (ESM): workers' rights and consultative institutions, welfare provisions and equal opportunities. Section 4 assesses the impact of the most recent changes on poverty, employment and the sustainability of the welfare system. Then we turn to a detailed analysis of recent measures affecting provisions for the unemployed (Section 5). Section 6 concludes with policy recommendations on possible amendments to the Hungarian welfare system to improve its performance and sustainability. 


\section{THE LEGACY OF SOCIALISM AND THE TRANSITIONAL SHOCK}

The Hungarian welfare system had been built on Bismarckian foundations, with compulsory social insurance legislation implemented for industrial workers more than a hundred years ago and extended gradually throughout the 1930s (Szikra 2004; Inglot 2008). The Communist turn following the Second World War brought about the nationalization of industries, the dismantling of tripartite systems and full (as well as compulsory) employment. Social insurance rights had been extended to all employees, including agricultural workers, by the mid-1970s, thus close to full coverage of employees was achieved by the end of the 1980s (Szalai 1992; Csemniczki 2000; Szikra 2009). The regime paid no specific attention to ensuring equal opportunities to vulnerable groups, but did encourage the social mobility of the lower classes. ${ }^{1}$

The peaceful turn from the state socialist command economy to a democratic capitalist system was coupled with a transitional crisis. Employment dropped from over 71 per cent in 1990 to below 55 per cent by 1993 and continued to decline until 1997 (Duman and Scharle 2011). The initial shock can be attributed to the loss of export markets, followed by disruptions in supply caused by shifts in relative costs and relative demand in response to price liberalization and the removal of subsidies (Kornai 1993; Blanchard 1998). This was aggravated by the unfortunate combination of rapid privatization and a welfare policy focused on reducing labour supply (Balla et al 2008). ${ }^{2}$ Early pensions and parental leave benefits were used to compensate redundant workers on a large scale in fear that the transitional recession would lead to unmanageable levels of unemployment and, along with it, misery and social unrest (Vanhuysse 2004). ${ }^{3}$ By 1995 the share of benefit recipients among the working age population had reached 31 per cent (Duman and Scharle 2012).

Welfare services were reorganized to meet the challenges of a market economy. The public employment service (PES) remained under the control of central government and its capacity was substantially expanded during the early 1990s (Bódis 2012). The management of schools, nurseries, local infrastructure, social assistance and basic social services was devolved to local municipalities. This also entailed the development of some services that had been neglected by the Socialist regime, such as family counselling or home care for the elderly. However, some ill-designed institutional features of the new system soon led to large regional disparities in the quality and accessibility of services. ${ }^{4}$

A system of tripartite consultation was established in the early 1990s, although the legitimacy of both workers' and employers' organizations was weak (Neumann and Váradi 2012). The civil sector was very limited, but gradually gained strength and legitimacy to engage in consultations with the government.

Legislation on anti-discrimination and protection of minorities (neglected under state socialist rule) developed gradually but did not become a central issue until the preparations began for Hungary's accession to the European Union in 2004. The emerging new welfare system was overwhelmed by servicing the rapidly growing ranks of the unemployed and tended to leave vulnerable groups to the care of mushrooming NGOs. However, their capacities were negligible compared to the large and abrupt drop in the labour market opportunities of the Roma, older workers or the disabled. Access to services was especially limited in rural areas 
and the north east, precisely where it was most needed. The north eastern region, formerly dominated by heavy industry and agriculture, had been hit much harder by the transition and successive governments had proved unable to significantly reduce the regional dispersion in incomes and employment opportunities.

The transitional recession was followed by steady and relatively high growth in output and a brief period of increasing employment between 1997 and 2000. Most analysts agree that the road to economic recovery was paved by the austerity package in 1996 (the so called Bokros package), which put a break on fast growing government deficit and restored macroeconomic balance (see, for example, Bartha 2012). The package however was assembled in haste, with little consultation even within the administration and relied mainly on across-the-board cuts, so that the structural problems of the welfare system remained unresolved. The cuts were nevertheless deep and abrupt. The real wage declined by 12 per cent in 1995 (see VaughanWhitehead 1998) for the insured unemployment benefit, the replacement rate was reduced from 75 to 65 per cent, its two phases merged into one and the ceiling was further reduced in real value. The pre-pension scheme was replaced by the considerably less generous pre-retirement unemployment benefit, earnings-related paid parental leave was abolished and insured flat-rate paid parental leave was replaced by means-tested assistance (Duman and Scharle 2011). ${ }^{5}$

\section{SITUATION AROUND THE YEAR 2000}

By the end of the millennium, Hungary had become one of the most successful countries in the region. The painful macroeconomic stabilization was complete, the financial system had been consolidated, privatization attracted a large inflow of foreign direct investment (FDI) and the country had been transformed into an export-oriented open economy (Bartha 2012). The period between 1998 and 2001 was characterized by steady, though mainly capital-based growth with a modest increase in employment.

The welfare system exhibited features inherited from the state socialist past but already included newly designed and reformed schemes introduced during the 1990s (Cerami 2009). It was also characterized by 'emergency' decision-making processes (Inglot 2008) and institutional volatility (Szikra and Tomka 2009) as rapid and frequent changes occurred in most welfare institutions. The accession process to the EU in the early 2000 s accelerated government efforts to increase social inclusion and the development of institutions securing equal opportunities. The main features of the ESM around the year 2000 are summarized in Table 6.1 . 
Table 6.1 Main features of the Hungarian social model

\begin{tabular}{|c|c|}
\hline Element of European Social Model & Situation in Hungary \\
\hline $\begin{array}{l}\text { Labour law and workers' rights } \\
\text { Employment and labour market rules }\end{array}$ & $\begin{array}{l}\text { Union coverage is moderate (one-third). } \\
\text { Relatively flexible employment protection legislation (EPL). }\end{array}$ \\
\hline $\begin{array}{l}\text { Workers' participation, information, } \\
\text { consultation }\end{array}$ & Weak due to political role of trade unions under state socialism. \\
\hline $\begin{array}{l}\text { Social dialogue and collective } \\
\text { bargaining; social partners' } \\
\text { involvement }\end{array}$ & $\begin{array}{l}\text { Stable institutions of tripartite negotiation (based on } 1991 \text { Labour } \\
\text { Code) but not very influential. } \\
\text { Firm- or industry-level wage bargaining and collective agreements } \\
\text { rare. }\end{array}$ \\
\hline Involvement of civil society & $\begin{array}{l}\text { Limited, though increasing during preparation for EU accession. } \\
\text { Number of civil organizations and their public funding growing. }\end{array}$ \\
\hline Decent wages or fair wages & Minimum wage $\sim 30$ per cent of average wage. \\
\hline $\begin{array}{l}\text { Welfare systems/social } \\
\text { protection/inclusion }\end{array}$ & $\begin{array}{l}\text { Welfare system aimed at cushioning social effects of transition. } \\
\text { Dominated by cash transfers, based on a centralized social insurance } \\
\text { system. } \\
\text { Social assistance: easy to access but level is low. Fragmented } \\
\text { administration (devolved to municipalities). } \\
\text { Social inclusion in focus during preparations for EU accession } \\
\text { (preparing Joint Inclusion Memoranda). }\end{array}$ \\
\hline $\begin{array}{l}\text { Public services and services of general } \\
\text { interest }\end{array}$ & $\begin{array}{l}\text { Public employment service (PES) focuses on administering benefits; } \\
\text { active labour market programmes are underdeveloped. } \\
\text { Fragmented administration and very uneven distribution of services: } \\
\text { access and quality is much higher in urban areas. } \\
\text { Preventive and rehabilitation services are poorly developed. } \\
\text { Public education fails to compensate for disadvantaged background. }\end{array}$ \\
\hline Social expenditure & Around 15 per cent of GDP. \\
\hline Taxation & $\begin{array}{l}\text { Progressive Personal Income Tax (PIT). } \\
\text { High social security contributions, tax wedge on minimum wage is } \\
\text { high ( } 48 \text { per cent). }\end{array}$ \\
\hline $\begin{array}{l}\text { Equal opportunities /anti- } \\
\text { discrimination }\end{array}$ & $\begin{array}{l}\text { Anti-discrimination legislation (enacted in } 1998 \text { and 2003) conforms } \\
\text { to EU standards but not systematically enforced. } \\
\text { Institutionalized consultation with women's organizations started in } \\
2000 \text { in the Ministry of Social Affairs. } \\
\text { Access to public services by people with disabilities is not fully } \\
\text { provided. Disabled and the Roma face discrimination at work. } \\
\text { Female wage gap gradually declining: around } 15 \text { per cent in } 2000 \text {. } \\
\text { Maternal employment rate low, partly due to long leaves and scarce } \\
\text { child-care services for small children. } \\
\text { Women underrepresented in politics. }\end{array}$ \\
\hline Regional cohesion/development & $\begin{array}{l}\text { Large and stable regional variation in access to services, regional } \\
\text { development projects poorly allocated/implemented. }\end{array}$ \\
\hline
\end{tabular}

Sources: Visser (2006), Neumann and Váradi (2012), Scharle (2012a); Benedek et al 2006; Bugarszki 2006; Szikra and Tomka 2009; Majtényi (2009), Lovász (2012), Szikra (2011). 


\subsection{Consultations: Strong Role for a Tripartite Body}

Unions had relatively strong consultative rights and their leaders enjoyed a protected position around 2000. At the same time, membership in trade unions remained relatively low, as trust in these institutions proved difficult to (re)establish partly because they were often associated with the previous regime, in which they had a role in implementing some of the Party's major decisions on welfare, especially social insurance. ${ }^{6}$ As a consequence, unions were not very influential in negotiations with the government (Neumann and Váradi 2012). Accepted among the first fundamental laws of the new democracy in 1991, the Labour Code provided extensive labour rights and social protection for employees and set up a balanced system for labour negotiations through a tripartite body (Council for the Negotiation of Interest $-\mathrm{CNI}$ ) comprising delegates of trade unions, employees and the state. This body functioned, with short interruptions, throughout the 2000s and its tasks included, among other things, the direct setting of the minimum wage and recommendations for wage increases to be then used as a range for collective bargaining at decentralized level. This implied a significant change in wage determination. Since 1991 the minimum wage had been adjusted regularly, once a year. At the same time, the fact that trade unions were not genuine grassroots organizations, but often detached from their members made it easier to weaken this institution repeatedly around 2000 and later, in 2010.

\subsection{The Welfare System}

The welfare system was dominated by cash transfers, while social services, despite rapid development during the 1990s, remained lacking in their range, quality and capacity. In the Socialist regime, social provisions primarily took the form of in-kind benefits, price subsidies, full employment, compressed wage distribution and nearly universal access to social insurance (Szalai 1992). Some social assistance was available to the needy but was meant primarily for the elderly and the disabled, as working age adults were expected to be earning their keep through work. Services for rehabilitation of work capacity or counselling and assistance in crisis situations (such as illness, death, mental health problems or domestic violence) had been marginal (Pik 2001). ${ }^{7}$ Although the need for such services was recognized during or after the political transition, materializing in the Act on Social Provisions in 1993 and on Child Protection in 1997, successive governments focused their efforts on providing income replacement to the growing pool of the unemployed. Besides important developments (such as the establishment of a network of family centres and child welfare centres), services for marginalized groups or problems received much less attention and financial resources than cash-transfers (Bugarszki 2004).

Insurance-based disability pensions, maternity or parental leave benefits (including the three-year paid leave) had already been important parts of the Socialist regime and were not much affected by the transition to a market economy. A major deviation from the Bismarckian and state socialist past was the partial privatization of the pension system in 1996, in response to growing concerns about the long-term sustainability of the pay-as-you-go system and the 
(perceived) need to promote individual savings (Müller 1999; Orenstein 2008). The privatization, as we will show later, has recently been reversed, implying that the Bismarckian centralized social insurance system has remained dominant in the country.

\subsection{Heavy Taxation and Regional Inequality}

Another feature common to most post-socialist member states was the heavy taxation of labour. In Hungary, this coexisted with relatively easily accessible early pensions and other cash transfers, which proved to be an unsustainable combination. The financing of social provisions required high tax rates, which curbed economic performance and labour demand. The resulting long-term unemployment and inactivity among the working-age population in turn led to longterm poverty and social exclusion (World Bank 2001). Thus the vicious circle closed, as these social disadvantages generated the need for further welfare spending (Cseres-Gergely and Scharle 2008). The problem of high taxes on labour was aggravated by the inappropriate design of the personal income tax and social security contributions, which further increased the cost of unskilled labour. The tax wedge of the minimum wage was 48 per cent in 2000, the second highest in Europe (OECD 2002).

Finally, the regional disparities in economic development and employment levels were aggravated by the institutional choices made early on in the transition, which established a very fragmented municipal system and allocated considerable welfare responsibilities to local governments. Social assistance and the most important social services were devolved to the municipalities, which supplemented financing by the central state. Poor localities, however, could contribute less. As a result, access to services remained uneven across regions: health care and social services were often unavailable, poorly staffed or of lower quality in small villages, especially in the north-eastern and the southern parts of the country, exactly where the need was greatest (Orosz 2001; ÁSZ 2004).

\subsection{Equal Opportunities}

The right to equal opportunities and protection against discrimination conformed to European standards in the year 2000 but with significant gaps in implementation. The ban on discrimination was established by the Constitution of 1989 and further strengthened in 1998 (for disabled citizens) and in 2003, on the eve of EU accession. A national strategy for the social inclusion of disabled citizens was endorsed in 1999. A dedicated unit dealing with Equal Opportunities for Women and Men was set up within the Ministry of Social and Employment Affairs in 2000 and a consultative body with women's organizations was established in the same year. The 2003 legislation ensured the right of equal access to health care, social services, rehabilitation and work opportunities to all citizens, and banned discrimination on the basis of disability, gender, sexual orientation, ethnicity or religion. The Equal Treatment Authority was established in 2005 to enforce and implement the Act of 2003 and provide legal remedy for those experiencing discrimination. However, as reported by scholars and human rights watchdogs (for example, Majtényi 2009; HCLU 2013; GWI 2013), improvements in daily 
practice remained limited. Roma and disabled jobseekers continued to face discrimination in all areas of life, including employment and access to public services (for example, Sik and Simonovits 2010).

While female employment was close to the EU average, the employment of mothers with small children was below 10 per cent in the early 2000s (Köllö 2009). This was due mainly to the traditional design of family policies, which favoured home care for children below three years of age by providing relatively generous parental leaves and limited funding for formal day-care institutions. Following the tradition of state socialism, the vast majority of working women were employed full time. However, the male/female wage gap was smaller than before the transition: it fell from 36 to 15 per cent between 1986 and 2003 (adjusted for educational composition, Lovász 2008, 2012). Despite efforts to establish the most important institutions of gender equality, women's participation in public life remained limited in the maledominated political arena, especially at the national level. ${ }^{8}$

\section{CHRONOLOGY OF MAIN POLICY MEASURES SINCE 2000}

The welfare reforms of the past fifteen years have been shaped by two major influences: the political cycle and recurrent fiscal crises, the most recent of which concurred with the global financial crisis. Let us first describe the economic and political background and then outline the most important policy developments.

\subsection{The Economic and Political Context of Social Policy Making in Hungary}

The economy enjoyed healthy growth of around 4.5 per cent until 2005, when it began to slow down slightly. The relative importance of the various factors leading to the slowdown are still debated, but most experts agree that government overspending and labour market distortions played an important role. Between 2000 and 2006, welfare spending rose from 27.6 per cent to 31.8 per cent of the GDP, while the budget deficit climbed to 9 per cent by 2006 . The unavoidable austerity measures imposed in late 2006 by the re-elected Socialist-Liberal coalition helped reduce the deficit to 3.3 per cent by 2008 , but at the expense of stifling economic growth and provoking social unrest.

The build-up of the fiscal imbalance can be attributed partly to unresolved structural distortions in the economy and partly to intensifying political polarization. ${ }^{9}$ The initial choice of a policy mix dominated by passive (rather than active) labour market measures proved difficult to reverse and had become a hindrance to employment growth. The doubling of the minimum wage (discussed in more detail below) in 2001-2002 only deepened the problem by further reducing demand for unskilled labour.

The elections in 2002 were won by the Liberal-Socialist coalition, but the result was very close. Seeking to reaffirm their popularity, the new government decided to keep its promise of raising public sector wages and pensions, while also maintaining mortgage subsidies and family benefits favouring the middle class voters of the previous government (Ohnsorge-Szabó 
and Romhányi 2007). ${ }^{10}$ As a result, spending on social provisions increased from 14.9 to 17.7 per cent of GDP between 2000 and 2006. Increasing unemployment and the austerity measures of 2006 fuelled the already existing popular discontent against politics in general and the ruling Socialist Party in particular, peaking in violent riots in 2006. These processes together strengthened anti-communist and populist right-wing sentiments and led to the landslide victory of the Conservative coalition at the 2010 elections. ${ }^{11}$

Already struggling with a slowdown of the economy starting in 2006, Hungary was hit hard by the financial crisis: GDP fell by almost 8 per cent between 2008 and 2009 and has been stagnating ever since (HCSO 2012). At the same time, total government expenditure on social protection was cut from 18.6 per cent in 2009 to 17.8 per cent in 2010 and further to 16.1 in 2012 (Eurostat 2013). While most high income countries have increased social spending in real terms since the outbreak of the crisis, Hungarian governments have cut spending by reducing both the amount of and access to cash transfers and cutting the budgets of service providers (ILO 2010). The Socialist government of 2009, which held a one-year mandate to handle the economic crisis, froze the nominal value of family provisions and social assistance, abolished the thirteenth-month pension and tightened the behavioural conditions of social assistance in 2009. The succeeding Conservative government went further by decreasing the nominal value of social assistance, abolishing early pensions and reducing the duration of the insured unemployment benefit from nine to three months in 2011. We devote special attention to the post-2010 developments as these entailed both paradigmatic and parametric reforms of nearly all areas of the welfare system.

\subsection{Welfare Policy becoming Political Battlefield}

Welfare policy has been increasingly subordinated to the political struggle between left and right. The Conservative governments of 1998-2002 and 2010-2014 promoted a workfare agenda, tended to rely less on consultations and ignored equal rights issues. While workfare reforms were moderate in their first term, the second Conservative government used its twothirds majority to introduce major changes in all elements of the social model. The three Socialist governments serving between 2002 and 2010 had no similarly strong agenda of their own. Their welfare policies were designed mainly in response to recommendations from the European Commission, welfare policy experts or, in an emergency manner, driven by macroeconomic instability caused by earlier overspending. As the political arena has grown increasingly polarized over the past decade, the two ends of the political spectrum have reduced efforts to seek consensus and often eradicated the reforms introduced by their opponents. This implied constant changes in the major elements of the social model and practically made any long-term reform unfeasible (Körösényi 2012).

The welfare cuts implemented by the new government elected in 2010 unfolded into a radical turn in the social model as part of a wider reform agenda aimed at changing the social structure, ousting the old elite and eradicating all remnants of the socialist past, which the government believes to be the main barrier to the country's prosperity. Their strategy rests on three pillars: 
(i) Centralization. The government has centralized public education, health services and public works schemes (formerly maintained by municipalities), nationalized compulsory savings in private pension funds and centralized child protection and institutional care for the disabled (formerly run by regions). The declared aim of these measures was to increase efficiency, but they also implied a loss of local autonomy and savings for the public budget.

(ii) Redistribution to the middle and the top. The explicit intention of the government is to strengthen the upper classes, even at the expense of the poor. The economic reasoning behind this is to boost investment and labour supply at the top, while the political motivation is to establish a new, non-communist elite. The 16 per cent flat-rate income tax and the generous child tax credit for high income families are intended to serve this aim.

(iii) Building a workfare regime. The government has curbed access to disability benefits and early pensions, abolished vocational early pensions, reduced the amount and duration of unemployment benefits and tightened behavioural conditions both by introducing unprecedentedly harsh sanctions and by extending the public works programme. This also implied reduced funding for all other active labour market policies, including training.

\subsection{Main Changes to the Hungarian Social Model since 2000}

\subsubsection{Rights and Consultation: unilateral wage policies}

The Conservative government of 1998-2002 tried to curtail social dialogue institutions within the government by weakening the remit of the Tripartite Council's secretariat and reducing the power of the Tripartite Council (Table 6.2a). These attempts were aborted after the European Commission's decision to interrupt the pre-accession negotiations until the government withdrew its plans to dismantle social dialogue. The succeeding Socialist-Liberal government restored and to some extent strengthened consultations. The returning Conservative government of 2010-2014 however proceeded with their own agenda to abolish the National Council for the Reconciliation of Interests (OÉT). OÉT was replaced by the new Economic and Social Council (NGTT), which does not have the same negotiating power as the previous council, for instance on minimum wages; nor does it make recommendations on wages for more decentralized levels of collective bargaining. 


\begin{tabular}{|l|l|l|}
\hline 1998-2002 & 2002-2010 & $\mathbf{2 0 1 0 - 2 0 1 4}$ \\
\hline $\begin{array}{l}\text { Attempts to weaken tripartite } \\
\text { national level negotiations }\end{array}$ & $\begin{array}{l}\text { There is consultation though not } \\
\text { fully transparent and no } \\
\text { systematic feedback to } \\
\text { stakeholders. } \\
\text { Slow improvement in } \\
\text { involvement of social partners }\end{array}$ & $\begin{array}{l}\text { Dismantled tripartite } \\
\text { negotiations. } \\
\text { No genuine attempt to consult } \\
\text { with social partners (or only with } \\
\text { a selected group of employers), }\end{array}$ \\
\hline Doubled minimum wage (MW) & $\begin{array}{l}\text { Wage rise of civil servants, } \\
\text { including public health and } \\
\text { education. } \\
\text { Increased gross MW. }\end{array}$ & $\begin{array}{l}\text { Increased gross MW } \\
\text { New Labour Code (LC) cut } \\
\text { worker and union rights, } \\
\text { increased freedom of employers } \\
\text { to define working conditions. } \\
\text { New LC constrained right to } \\
\text { strike and bargain collectively }\end{array}$ \\
\hline
\end{tabular}

Sources: Duman and Scharle (2011), Neumann and Váradi (2012), GHK (2012), Laki et al. (2013), Szabó (2013).

While the differing attitudes of Conservative and Socialist governments to social consultation are self-explanatory, their wage policies require some explanation. Both Conservative cabinets (lead by FIDESZ - Young Democrats' Alliance) increased the minimum wage (in 2001-2002 and in 2011); however, this happened not in response to demand from trade unions and workers, but as part of workfare reforms. In fact, the Conservative government decided on the increases unilaterally in both cases (Neumann and Váradi 2012). First, the aim was to boost labour supply by increasing the gap between the minimum wage and social assistance (Köllö 2012). The latest rise was meant to compensate for the abolition of the earned income tax credit (justified by the introduction of the flat tax in 2011). As a result, the latest rise in the gross minimum wage in fact translated into a small drop in its net amount, which the government sought to 'correct' by strongly encouraging employers to increase wages (Szabó 2013). The public sector wage rise under the Socialists in 2002 was indirectly triggered by the wage distortion induced by the preceding rise in the minimum wage, which had led to strikes and protests in public health care and education (Duman and Scharle 2011; Neumann and Váradi 2012).

The new Labour Code introduced in 2011 was aimed at increasing labour market flexibility. While this may be interpreted as fitting in with the flexicurity agenda promoted by the EU, it is questionable on several accounts. First, the old Code already ensured a fairly high level of flexibility compared to old EU member states. Second, the increase in employers' rights was not accompanied by measures to strengthen the income security of jobseekers (on the contrary, as we shall describe in the case study on unemployment benefits). Lastly, although the amendments to the Code had been initiated by employers' lobbies, the government did not 
initiate open consultations about it until the unions protested (Laki et al. 2013; Szabó 2013). The ILO reacted strongly to a number of changes in the Labour Code. In the end, while some of the rights of trade unions were restored, on the whole the new Code is heavily biased in favour of employers (Kollonay-Lehoczky 2012).

\subsubsection{Changes in the Welfare System}

As already mentioned, successive governments rarely followed the approach of their predecessor in any policy area and welfare policy was no exception. Although all governments agreed on the need to tackle long-term unemployment and poverty, they disagreed on the nature of the solution. The Conservative government of 1998-2002 focused mainly on supply side incentives, ${ }^{12}$ while their successor sought to improve access to services (most importantly, high quality public education) and social assistance. The second Socialist government (2006-2010) was the first to introduce a targeted wage subsidy in order to increase demand for unskilled workers and it also attempted (with limited success) to activate disability benefit recipients by imposing behavioural conditions. Towards the end of their term, however, they gave in to political pressures to extend public works and reduce the generosity of social assistance, an issue we describe in detail in the case study. This was one of the few measures that the Conservative government taking over in 2010 did not abolish, but even extended, although under a new name and a new, centralized administration.

Table 6.2b Main changes in ESM elements: welfare, Hungary, 1998-2014

\begin{tabular}{|c|c|c|}
\hline 1998-2002 & 2002-2010 & 2010-2014 \\
\hline $\begin{array}{l}\text { Repeated cuts in unemployment } \\
\text { benefit duration and amount. }\end{array}$ & $\begin{array}{l}\text { Repeated cuts in unemployment } \\
\text { benefit duration/amount. }\end{array}$ & $\begin{array}{l}\text { Cut duration of unemployment } \\
\text { benefit from } 9 \text { to } 3 \text { months. }\end{array}$ \\
\hline $\begin{array}{l}\text { Two social assistance schemes } \\
\text { merged and made conditional on } \\
\text { public works organized by local } \\
\text { municipality. }\end{array}$ & $\begin{array}{l}\text { Public works extended in } 2009 \text { and } \\
\text { behavioural conditions of social } \\
\text { assistance tightened. } \\
\text { Social assistance extended to } \\
\text { function as a minimum income } \\
\text { scheme in } 2006 \text {, capped at } \\
\text { minimum wage in } 2007 \text { and made } \\
\text { flat rate in } 2009 \text {. Nominal level } \\
\text { frozen in } 2009 \text {. }\end{array}$ & $\begin{array}{l}\text { Public works further extended and } \\
\text { centralized. } \\
\text { Social assistance tied to public } \\
\text { works, arbitrary behavioural } \\
\text { conditions and harsh sanctions } \\
\text { imposed. } \\
\text { Nominal level of social assistance } \\
\text { cut from } 20 \text { to } 15 \text { per cent of } \\
\text { minimum wage in } 2010 \text {; no increase } \\
\text { since. }\end{array}$ \\
\hline $\begin{array}{l}\text { Emphasis is on cash-transfers rather } \\
\text { than active labour market policies } \\
\text { (ALMP). }\end{array}$ & $\begin{array}{l}\text { Individual Action Plan (IAP) for } \\
\text { unemployment benefit and } \\
\text { unemployment assistance recipients } \\
\text { introduced in } 2005 \text {. } \\
\text { Continued dominance of traditional } \\
\text { ALMP with weak monitoring and } \\
\text { targeting, but some increase in } \\
\text { personalized services in EU-funded } \\
\text { programmes. }\end{array}$ & $\begin{array}{l}\text { Drastic cut in PES staff. } \\
\text { Cuts in ALMP funding, abolished } \\
\text { compulsory Individual Action Plans } \\
\text { for registered unemployed, } \\
\text { continued EU-funded ALMP } \\
\text { without strengthening monitoring. } \\
\text { Reduced share of training within } \\
\text { ALMP budget, abolished tax credit } \\
\text { for training within firms. }\end{array}$ \\
\hline
\end{tabular}




\begin{tabular}{|c|c|c|}
\hline 1998-2002 & 2002-2010 & 2010-2014 \\
\hline $\begin{array}{l}\text { Continued pension reform: gradual } \\
\text { increase of statutory pensionable } \\
\text { age. } \\
\text { Decreased contribution rate to } \\
\text { private pension pillar. } \\
\text { Kept generous early/disability } \\
\text { pensions. } \\
\text { Nationalized self-governing } \\
\text { tripartite body of social insurance } \\
\text { funds. }\end{array}$ & $\begin{array}{l}\text { Continued pension reform: increase } \\
\text { of pensionable age. } \\
\text { Attempted to curb access to } \\
\text { early/disability pensions } 2006 \text {, } \\
\text { extended job search requirement to } \\
\text { disability benefits } 2008 \text { and } \\
\text { launched ALMP for disabled job } \\
\text { seekers (including mentoring, } \\
\text { counselling and wage subsidies). }\end{array}$ & $\begin{array}{l}\text { Abolished private pension pillar, } \\
\text { transferred assets to the public } \\
\text { pension fund and the treasury. } \\
\text { Abolished all early pensions. } \\
\text { Tightened access to disability } \\
\text { benefits, reduced amount for those } \\
\text { with more work capacity retained. } \\
\text { Continued ALMP for disabled job } \\
\text { seekers, established separate PES } \\
\text { network. }\end{array}$ \\
\hline No change in social expenditure. & $\begin{array}{l}\text { Up to } 2009 \text { slow rise: } 14.9 \text { to } 18.6 \\
\text { per cent of GDP. Decrease in real } \\
\text { terms from } 2009 \text {. }\end{array}$ & $\begin{array}{l}\text { Dropped to } 17.1 \text { per cent of GDP by } \\
2011 \text {. }\end{array}$ \\
\hline Cut in social security contributions. & $\begin{array}{l}\text { Tax wedge on minimum wage cut } \\
\text { from } 48 \text { to } 36 \text { per cent. }\end{array}$ & $\begin{array}{l}\text { Flat personal income tax (PIT) at } 16 \\
\text { per cent, abolished tax credit for low } \\
\text { income earners. } \\
\text { Introduced generous child tax } \\
\text { allowance (especially for third } \\
\text { child). } \\
\text { Tax wedge on minimum wage } 49 \\
\text { per cent. } \\
\text { Social security contributions } \\
\text { increased by } 1 \text { per cent. }\end{array}$ \\
\hline
\end{tabular}

Sources: Duman and Scharle (2011), Nagy (2012), Szikra (2014).

The activation of disabled jobseekers is another area in which the past two governments followed a similar approach. The Socialist government introduced a new, insurance-based rehabilitation allowance in 2008, which was granted to new claimants of the disability pension or disability benefit whose work capacity could be partially or fully rehabilitated. The benefit rate was roughly the same as the disability pension and it was granted for the duration of the rehabilitation programme but only up to a maximum of three years. Motivated mainly by the need to cut public spending, but nevertheless in line with the flexicurity approach, the new Conservative government further tightened access to early and disability pensions (Budapest Institute 2012). The initiative included a redesign of the system according to which two main benefit types replaced the earlier, rather complicated range of benefits and pensions: existing claims of working age beneficiaries were reassessed, and those who maintained their benefit are obliged to cooperate with local rehabilitation centres unless they have lost all capacity to work.

\subsubsection{Equal Opportunities and Family Policies: Influenced by the EU until 2010}

Equal opportunities is an area in which the influence of EU accession is probably the most evident, at least until 2010 (see Table 6.2c). Active labour market policy (ALMP) and PES practices were adjusted to meet EU recommendations on providing equal access for vulnerable 
groups (Váradi 2012) and EU funding was used to launch projects on the de-segregation of poor and Roma children in public education. However, the recent centralization of the education system and the curricular reform is likely to undermine even the modest achievements of the previous government (for example, the reduction of competence development in the curricula of vocational schools and the reduction of funding available for training schemes) and increase segregation of Roma children.

Developments in work/life balance and gender equality policies are mixed, combining a Conservative rhetoric with incentives for female labour supply. Based on alternative reports of civil organizations, a recent UN review states that the Hungarian government's 'orientation may represent a regressive approach to gender roles' and that 'this orientation increases prevalence of gender stereotypes by portraying women mainly, if not exclusively, in the role of mothers and caregivers' (UN 2013:2). ${ }^{14}$ The Council for Social Equality among Women and Men has been disbanded and thus consultation between the government and women's organizations and gender experts has practically ceased. The responsibility for promoting gender equality is now shared between two ministries. ${ }^{15}$ The reconciliation of family duties and paid employment has been relegated to the Department of Family Policy within the newly established Ministry of Human Resources but without a sufficient allocation of staff and budget (Juhász 2012), while the issue of women's employment has been moved to the Ministry of the National Economy. ${ }^{16}$

Family policies have remained centred on long parental leaves despite EU and OECD recommendations to increase maternal employment and the number of nursery places. The previous government attempted to cut the duration of the flat rate leave (GYES) and to develop day-care capacities, though with limited success. The new Conservative government restored the flat rate leave and kept paternity leave at five days, ignoring the recent EU recommendation to increase it to at least four weeks. ${ }^{17}$

At the same time, the Conservative government introduced compulsory kindergarten from three years of age, devoted substantial resources to developing capacities in day care (both nurseries and kindergarten) using Structural Funds (Scharle and Samu 2013) and increased the ceiling on parental fees in order to boost the supply of day-care services. This has contributed to a slight increase in nursery attendance from 11 to 13 per cent of children up to three years of age (although still far from the Barcelona target of 33 per cent). The government has also increased wage subsidies to employers to support mothers returning to work after maternity leave. 
Table 6.2c Main changes in ESM elements: equal opportunities, Hungary, 1998-2014

\begin{tabular}{|c|c|c|}
\hline 1998-2002 & $2002-2010$ & 2010-2014 \\
\hline $\begin{array}{l}\text { Legislation on equal } \\
\text { opportunities for people } \\
\text { living with disabilities in } \\
\text { 1998, very slow } \\
\text { implementation. } \\
\text { Established equal } \\
\text { opportunities unit in welfare } \\
\text { ministry in } 2000 \text {. }\end{array}$ & $\begin{array}{l}\text { Law on equal opportunities in } \\
2003 \text {. } \\
\text { Equal Treatment Agencies set up } \\
\text { in } 2005 \text {, understaffed. } \\
\text { Gender equality unit within } \\
\text { Ministry of Welfare. }\end{array}$ & $\begin{array}{l}\text { New Constitution includes ban on } \\
\text { discrimination (except for sexual } \\
\text { orientation). } \\
\text { Dedicated social inclusion unit in the } \\
\text { Ministry of Human Resources responsible } \\
\text { for the integration of the Roma and } \\
\text { people with disabilities. } \\
\text { Gender equality unit dissolved. }\end{array}$ \\
\hline \multirow[t]{4}{*}{ No genuine effort. } & $\begin{array}{l}\text { Target ALMP to vulnerable } \\
\text { groups (people with disability, } \\
\text { long-term unemployed, Roma, } \\
\text { unskilled, mothers after parental } \\
\text { leave). } \\
\text { PW extended in } 2009 \text {, decreasing } \\
\text { assistance and increasing control } \\
\text { over long-term unemployed (and } \\
\text { Roma). } \\
\text { New wage subsidy for } \\
\text { disadvantaged job seekers } 2007 \text {, } \\
2009 \text {. }\end{array}$ & $\begin{array}{l}\text { Public works run by Interior Ministry } \\
\text { since } 2011 . \\
\text { Loopholes in implementation allow for } \\
\text { discriminatory practices. } \\
\text { Cuts in Social Security Contributions } \\
\text { (SSC) for disadvantaged jobseekers and } \\
\text { employees (2012). }\end{array}$ \\
\hline & $\begin{array}{l}\text { Raised employers' penalty on } \\
\text { disabled quota } 2004,2010 \text {. }\end{array}$ & $\begin{array}{l}\text { Eased disabled penalty by increasing } \\
\text { threshold from } 20 \text { to } 25 \text { workers in } 2012 \text {. } \\
\text { Plans to develop rehabilitation services } \\
\text { for disabled workers, implementation } \\
\text { slow. }\end{array}$ \\
\hline & $\begin{array}{l}\text { Attempt to improve targeting of } \\
\text { local development funds, and to } \\
\text { make such funding conditional on } \\
\text { equal opportunities strategy. }\end{array}$ & $\begin{array}{l}\text { Centralized planning and management of } \\
\text { local development projects in depressed } \\
\text { areas. }\end{array}$ \\
\hline & $\begin{array}{l}\text { Cut flat-rate parental leave } \\
\text { (GYES) from } 3 \text { to } 2 \text { years in } 2009 \text {, } \\
\text { lowered administrative burden for } \\
\text { nurseries and kindergartens. } \\
\text { New child-care service targeted } \\
\text { towards disadvantaged ( } \sim \text { 'sure } \\
\text { start'). } \\
\text { New conditional cash transfer } \\
\text { (CCT) for attending kindergarten. }\end{array}$ & $\begin{array}{l}\text { Increased 'GYES' back to } 3 \text { years } 2010 \text {, } \\
\text { lowered admin for nurseries/ } \\
\text { kindergartens, cut paid holiday for } \\
\text { mothers returning from maternity leave, } \\
\text { increased ceiling on parents' fees for } \\
\text { nurseries (as an incentive to increasing } \\
\text { service capacity). } \\
\text { Compulsory kindergarten attendance } \\
\text { from age } 3 \text { (from 2014). } \\
\text { Cut funding for targeted services, kept } \\
\text { CCT. }\end{array}$ \\
\hline & $\begin{array}{l}\text { Legislation and extensive training } \\
\text { programme to promote de- } \\
\text { segregation in public education. } \\
\text { Public education reform to } \\
\text { promote basic skills development. } \\
\text { Expanded basic skills training for } \\
\text { low skilled job seekers. }\end{array}$ & $\begin{array}{l}\text { Weakened mandate of the Ombudsman to } \\
\text { investigate discriminatory practices } \\
\text { Weakened efforts to reduce segregation in } \\
\text { public education. } \\
\text { Reduced compulsory school age to } 16, \\
\text { trimmed basic skills content in curricula } \\
\text { of vocational schools, cut funds for } \\
\text { teacher training in competence } \\
\text { development. }\end{array}$ \\
\hline
\end{tabular}

Sources: Lannert (2004), Juhász 2013; EWL 2012; Lovász (2012), OECD (2008, 2013), Altwicker-Hámori and Köllö (2013). 


\section{IMPACT OF RECENT MEASURES}

\subsection{Lack of Economic Recovery}

Despite relatively well-designed measures to protect employment, the global financial crisis has had grave effects on the Hungarian labour market, as firms have tended to respond by cutting their workforce rather than by reducing working hours (Köllö 2011). Between 2007 and 2010 unemployment rose to 11.2 per cent (up by 3.8 percentage points) and has stagnated at 11 per cent ever since. Employment fell to 55.4 per cent by 2009 and only returned to its pre-crisis level of 57.2 per cent in 2012. However, correcting the latter figure for the increase in the number of workers employed in public works programmes would cancel out much of this increase.

The measures taken by the Socialist government (formed in 2009 with a mandate to handle the crisis) in 2009-2010 were quite successful in reducing the deficit and curbing job losses, although their efficiency was considered poor in international comparison (OECD 2010a). ${ }^{18}$ The 225 billion HUF spent on reducing labour costs in 2010 (the employers' social security contribution rate was decreased by 5 percentage points and the lump-sum health contribution abolished) was estimated to have increased employment by $0.3-2.8$ per cent in the short run and by $0.5-1$ per cent in the long run (Elek and Scharle 2011).

The newly elected Orbán government hoped to jumpstart growth by introducing a flat rate income tax regime and financed that by nationalizing private pension funds and imposing temporary taxes on large (mainly multinational) firms. Rather than boost growth, this strategy led to a loss of confidence on the part of both consumers and the business sector (OECD 2012b).

The inconsistent and often improvised economic strategy of the Orbán government is likely to further delay economic recovery. Despite cuts in corporation tax for SMEs and the automobile industry, overall investments have not increased, probably due to the general uncertainty of the business environment. ${ }^{19}$

Labour market prospects are bleak. The increase in flexible contracting arrangements and the cuts in benefit levels and access to various welfare provisions have increased labour supply: the activity rate rose from 61.5 per cent in 2008 to 64.3 per cent by 2012 . However, the increase in the minimum wage and social insurance contributions is likely to curb the increase in labour demand, so that the overall impact on employment is likely to be zero or at best modest, while unemployment may remain at its current level of around 11 per cent.

The fiscal sustainability of the welfare system improved as the recent cuts in access to or the amount of early pensions, disability benefits and unemployment provisions generate permanent savings to the budget. The increasing emigration of skilled workers may cancel out some of these gains as it worsens the economic dependency ratio (Sik 2012). It is also doubtful whether these savings can be maintained against political pressures. The government has already announced plans to reintroduce the thirteenth month pension (appealing to pensioners who usually vote for the Socialists). Short-term political gains aside, the next government to 
be elected in 2014 will be forced to tackle growing social exclusion and poverty, which will require more spending, at least until employment levels rise.

\subsection{Cuts and Reformed Tax Policy Leading to Increased Polarization and Poverty}

Prior analyses already predicted a substantial decline in income security and a decreased consumption of the lower classes as a result of tightening access and cutting the level of benefits (Benczúr et al. 2011). Recent income surveys confirm these effects, and indicate a polarization of society (Szívós and Tóth 2013). The relative poverty rate (calculated as 60 per cent of the median income) grew from 13.6 in 2009 to 17 per cent in 2012 (see Figure 6.1), and child poverty increased from 21 to 26 per cent in the same period (ibid.: 42).

Figure 6.1 Change in indicators of income inequality and poverty, Hungary, 1987-2012

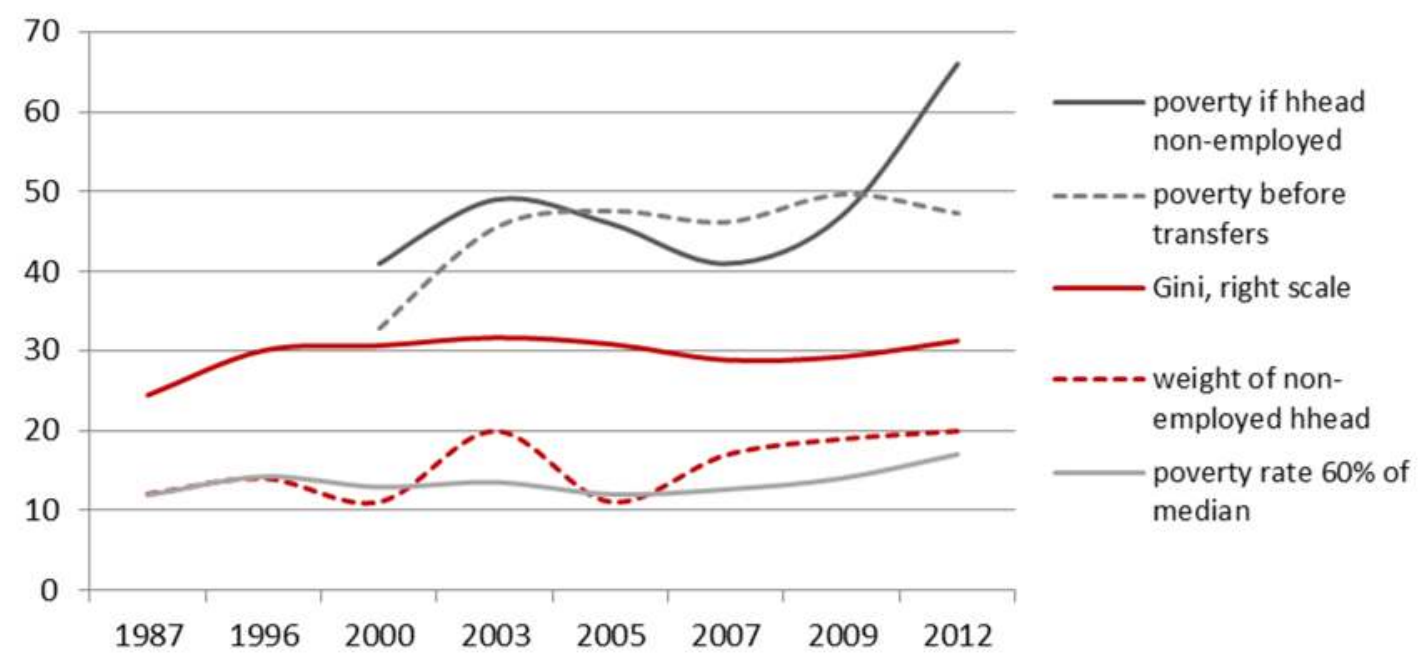

Note: weight of non-employed household head (hhead) shows the share of this group in the decomposition of overall income inequality.

Source: Tárki (2013)

The adaptation strategies of households with no link to the formal labour market are constrained by the loss of earlier connections linking them to the outside world and relations with the majority society disappear almost completely (Kotits 2012: 64). Unemployed households are increasingly isolated, especially in villages and especially their female members, which tends to reinforce traditional gender roles. Recent studies also report that the cut in the public works wage led to a loss of motivation of public workers and problems with 'discipline'.

Poverty increasingly has an 'ethnic' face: whereas approximately 5-10 per cent of the total population belongs to the Roma minority in Hungary, their share among the poor increased from 20 to 33 per cent between 2007 and 2012 (Szívós and Tóth 2013: 46.). No less than 90 per cent of Roma Hungarians live in severely deprived circumstances, including no possibility of eating meat every second day or affording proper heating during the winter (ibid. 47).

The austerity measures of the Orbán government also affected the public sector, where most workers have been able to retain their jobs but lost 10 to 35 per cent of their earnings in real 
terms between 2008 and 2011 (Altwicker-Hámori and Köllö 2013). Low-skilled, low-wage workers were hit hardest but their high-skilled counterparts started from relatively lower wage levels compared to similar employees in the private sector. The anticipated downsizing in healthcare and education was likely to affect the skilled labour force and will further adversely affect the position of women who are overrepresented in the public sector including among medium-skilled employees in public administration and health.

Wage developments in the public sector strongly affecte women's overall earning position since the public sector currently employs 36 per cent of the female labour force as opposed to only 18 per cent of males. The large shifts in the public sector's relative wage, on one hand, and women's strong exposure to these changes, on the other, had a decisive impact on the overall gender wage gap. Altwicker-Hámori and Köllö (2013) show that the movement towards a narrower gender gap was interrupted by the austerity measures of 1995-1998 and 2006-2010. According to the same authors the crisis brought about substantial changes in the position of the public sector within the wage distribution. In 2008 the public sector was strongly underrepresented in the lower tiers of the distribution, while in 2010 its share already amounted to 20-30 per cent in the 1st-20th percentiles. If we include participants in public works, the public sector became the dominant provider of jobs at the lower end of the wage distribution.

\subsection{Social Discontent}

Unlike in other countries, the severe wage cuts and the threat of dismissals have not led to large scale open protests in Hungary. The number of strikes in fact fell from 7-9 in 2008-2010 to 1 in 2011 and 3 in 2012 (ibid). Though there have been several demonstrations against the government since 2010, these tended to focus on political issues rather than economic ones. Important exceptions include the protests organized by policemen, firemen and professional soldiers against the reform of their early retirement schemes in 2011 and a march organized by the ruling Conservatives against the EU and the IMF in January 2012.

Table 6.3 summarizes the impact of recent welfare measures on labour market outcomes, sustainability and poverty. Further details on employment and unemployment are presented in the case study. 
Table 6.3 Impact of recent changes to the welfare system, Hungary

\begin{tabular}{|c|c|c|c|}
\hline ESM area & Labour market & Sustainability & Poverty \\
\hline Rights and consultation & $\begin{array}{l}\text { New Labour Code may } \\
\text { lead to worse labour } \\
\text { market conditions for } \\
\text { employees and decreasing } \\
\text { possibilities of legal } \\
\text { remedy. }\end{array}$ & $\begin{array}{l}\text { The lack of consultation } \\
\text { and consensus-seeking } \\
\text { might lead to less } \\
\text { sustainable decisions and } \\
\text { more failures of } \\
\text { implementation. }\end{array}$ & $\begin{array}{l}\text { Overall quality of } \\
\text { government decision- } \\
\text { making has declined due } \\
\text { to lack of consultation. } \\
\text { This also increases the } \\
\text { risk of implementation } \\
\text { failures, for example, in } \\
\text { ensuring equal access to } \\
\text { PWP and social } \\
\text { assistance. }\end{array}$ \\
\hline Welfare & $\begin{array}{l}\text { Decreased welfare } \\
\text { provision and access to } \\
\text { services might have a } \\
\text { negative effect on the } \\
\text { quality of the labour } \\
\text { force. Cuts in social } \\
\text { assistance and insecurity } \\
\text { lead to the acceptance of } \\
\text { low quality labour market } \\
\text { conditions and/or flow to } \\
\text { unregistered labour. }\end{array}$ & $\begin{array}{l}\text { Activity rate has } \\
\text { increased but long-term } \\
\text { unemployment remains } \\
\text { high. }\end{array}$ & $\begin{array}{l}\text { Large increase in income } \\
\text { inequality, poverty rate, } \\
\text { risk of poverty for } \\
\text { households with } \\
\text { unemployed/inactive } \\
\text { head. Polarization of } \\
\text { society. }\end{array}$ \\
\hline Equal opportunities & $\begin{array}{l}\text { Discrimination may have } \\
\text { decreased for disabled job } \\
\text { seekers (rise in penalty), } \\
\text { and increased for the } \\
\text { Roma (anti-Roma } \\
\text { prejudice widespread in } \\
\text { public discourse). } \\
\text { Increased exclusion of } \\
\text { women from the public } \\
\text { sphere and politics. } \\
\text { Increased sexist discourse } \\
\text { (also) in Parliament. }\end{array}$ & $\begin{array}{l}\text { Accelerating tendencies } \\
\text { of social exclusion and } \\
\text { anomie. This contributes } \\
\text { to weakening of } \\
\text { democratic institutions. }\end{array}$ & $\begin{array}{l}\text { Above-average increase } \\
\text { in the poverty rate of } \\
\text { Roma households and } \\
\text { probably of people with } \\
\text { disabilities. } \\
\text { Violence against women } \\
\text { and children in } \\
\text { households living in deep } \\
\text { poverty widespread. }\end{array}$ \\
\hline
\end{tabular}

Sources: Laki et al. 2013, TÁRKI (2013), Kollonay (2012).

\section{CASE STUDIES: RADICAL UNEMPLOYMENT BENEFIT REFORMS IN HUNGARY: WHAT CHANGES AND WHAT EFFECTS?}

\subsection{A Series of Radical Reforms}

Recent measures affecting unemployment provisions in Hungary have continued the earlier trend of reducing benefit levels and increasing incentives to engage in employment or public works programmes. The post-2010 measures are, however, exceptional in two respects: the depth of the cuts and the dominance of public works. Both trends and their magnitude are unprecedented in Europe. The expansion of public works programmes at the expense of traditional active labour market policies (ALMP) appears to be unique to Hungary, a 
phenomenon that Case Study 1 explores in depth. Only four countries in Europe have cut the duration of insurance-based unemployment benefits since the outbreak of the crisis in 2008 . While Denmark, Greece and Portugal kept the maximum at 11 months or longer, ${ }^{20}$ it was reduced from 9 to 3 months in Hungary, as shown in Case Study 2. Box 6.1 presents all the changes introduced up until 2010.

Box 6.1 Policy changes in unemployment insurance and assistance, Hungary, until 2010

\section{Introduced in the Late 1980s}

State-funded unemployment insurance was introduced in 1986 and a means-tested flat-rate unemployment assistance was introduced in 1992 for claimants who had exhausted eligibility for the insurance benefit (Nagy 2012). Initially, unemployment insurance was paid for a maximum of two years, while unemployment assistance was open-ended until 1995, when it was limited to two years. Last resort-type means-tested social assistance was open-ended. ${ }^{21}$ Table 6.4 presents the percentage of unemployed receiving the various types of benefit.

\section{Redesigned in 2000 with Stricter Rules on Eligibility}

Apart from minor cuts in the duration or amount of benefits, the system was left unchanged until 2000, when means-tested unemployment assistance was merged with the social assistance scheme and made available regardless of prior work history, but conditional on lack of work. This implied that the working poor were no longer eligible for it and no other assistance was put in its place.

The level of the new unemployment assistance was also cut from 80 to 70 per cent of the minimum old-age pension. The new scheme maintained the character of unemployment assistance because eligibility was conditional on cooperation with the job centre or the social work agency. In addition, the work test was considerably strengthened in an effort to focus more on activation and workfare (Frey 2001). Eligibility for the new scheme was also made dependent on claimants engaging in 30 days of public works (prior to accessing benefit) which was paid at the minimum wage. 
Table 6.4 Registered unemployed by type of benefit received, Hungary, 1990-2012 (\%)

\begin{tabular}{|l|c|c|c|c|c|c|c|}
\hline & $\mathbf{1 9 9 0}$ & $\mathbf{1 9 9 5}$ & $\mathbf{2 0 0 0}$ & $\mathbf{2 0 0 5}$ & $\mathbf{2 0 0 8}$ & $\mathbf{2 0 1 0}$ & $\mathbf{2 0 1 2}$ \\
\hline Unemployment insurance & 100 & 38.4 & 44.8 & 48.9 & 48.0 & 51.8 & 25.6 \\
\hline Pre-retirement UA & - & - & 2.9 & 2.0 & 1.8 & & \\
\hline Means tested UA & - & 49.1 & 36.9 & 49.1 & 50.1 & 47.2 & 74.4 \\
\hline Means tested SA & - & - & 13.2 & - & - & - & - \\
\hline School-leavers' allowance & - & 6.7 & 0.0 & - & - & - & - \\
\hline Pre-pension & - & 5.8 & 2.2 & - & - & - & - \\
\hline Total receiving some assistance & 100 & 100 & 100 & 100 & 100 & 100 & 100 \\
\hline $\begin{array}{l}\text { Those not receiving any assistance (\% of the } \\
\text { registered unemployed)* }\end{array}$ & 10.3 & 22.6 & 29.5 & 33.8 & 35.8 & 39.0 & 51.9 \\
\hline Registered unemployed ('000) & 47.4 & 507.7 & 390.2 & 409.5 & 442.3 & 582.7 & 559.1 \\
\hline Employed on public works schemes ('000) & n.a. & 21.7 & 30.5 & 38.2 & 35.6 & $96.0 * *$ & 112.9 \\
\hline
\end{tabular}

Note: *The increase in non-recipience is partly explained by the phasing out of the school-leavers allowance in 1996, and partly by the tightening of unemployment insurance and unemployment assistance rules. ** Authors' estimate based on government statistics on central government subsidies to municipalities. Sources: IE HAS 2002, 2008, 2013.

\section{Balancing income support with activation}

Besides a minor alteration of the unemployment insurance scheme in $2003,{ }^{22}$ there was no change to unemployment benefits until late 2005 when the socialist administration - possibly inspired by EU recommendations - redesigned the benefit system with the aim of providing strong incentives for job search, but at the same time adequate levels of income support. Unemployment insurance was renamed 'job search' provision, and behavioural conditions were further tightened (Frey 2006: 208). To encourage early exit from benefit receipt, the new unemployment insurance was heavily front loaded in 2006 and a reemployment bonus was introduced. ${ }^{23}$ The maximum duration of the first phase was reduced by 90 days but the average benefit amount increased considerably. ${ }^{24}$

In April 2006, unemployment assistance became a minimum income scheme, and the benefit amount dependent on equivalent family income (rather than per capita income). As intended, the redesigned allowance was more effective in reducing poverty, and especially child poverty, but also raised concerns about widening the unemployment trap, as there was no phasing out or disregard for those entering a job (Firle and Szabó 2007).

\section{Further cuts in the late 2000s}

The next reform was implemented in 2009 and affected only the means-tested scheme. Changes made to unemployment assistance were similar to those in 2000, except more severe. Recipients of the old unemployment assistance were divided into two groups: those considered 
able to work, and those too frail to do so. For the latter group, the benefit amount remained unchanged and the work test was removed. For the former, the benefit amount was flattened and considerably reduced and the work test extended to 90 days of public works a year, paid at least at a rate equivalent to the minimum wage. Public works remained a municipal responsibility and available funds were considerably increased.

The welfare reform implemented between 2010 and 2013 affected both insured unemployment benefits and unemployment assistance. Table 6.5 lists the measures that have affected unemployment provisions and summarizes their main effects that are further explored in the two case studies.

Table 6.5 Overview of measures affecting unemployment provisions, Hungary, 2010-2013

\begin{tabular}{|c|c|c|c|}
\hline $\begin{array}{l}\text { Dimension of } \\
\text { social model }\end{array}$ & Specific focus & Policy reforms & Effects \\
\hline $\begin{array}{l}\text { Welfare policy and } \\
\text { equal opportunities }\end{array}$ & $\begin{array}{l}\text { Social assistance } \\
\text { and public works } \\
2010-2012\end{array}$ & $\begin{array}{l}\text { Extended definition of suitable } \\
\text { job in } 2011 \\
\text { Expanded public works in } 2011 \\
\text { Centralised public works in } \\
2011 \\
\text { Cut public works wage in } 2011 \\
\text { No uprating of assistance } \\
\text { between } 2010 \text { and } 2011 \text { and } \\
\text { nominal cut from } 28,500 \text { to } \\
22,800 \text { HUF in } 2012 \\
\text { Extended behavioural } \\
\text { conditions to keeping a tidy } \\
\text { house in } 2012 \\
\text { Increased sanctions for refusing } \\
\text { suitable job offer in } 2012\end{array}$ & $\begin{array}{l}\text { Increasingly uneven access to } \\
\text { benefit } \\
\text { Anecdotal evidence on } \\
\text { increasing discrimination against } \\
\text { Roma } \\
\text { Stigma likely to have increased } \\
\text { and take-up declined } \\
\text { Poverty-reducing effect of social } \\
\text { assistance declined } \\
\text { Poverty rate increased, } \\
\text { especially for non-employed } \\
\text { households and for children } \\
\text { Limited evidence of labour } \\
\text { supply effects }\end{array}$ \\
\hline Welfare policy & $\begin{array}{l}\text { Insured } \\
\text { unemployment } \\
\text { benefit } \\
2011\end{array}$ & $\begin{array}{l}\text { Cut maximum duration of } \\
\text { insured unemployment benefit } \\
\text { from } 270+90 \text { to } 90 \text { days } \\
\text { Cut minimum duration from } 73 \\
\text { to } 36 \text { days } \\
\text { Reduced ceiling from } 120 \text { to } \\
100 \% \text { of the minimum wage } \\
\text { Raised prior contribution } \\
\text { requirement from } 364 \text { days over } \\
4 \text { years to } 360 \text { days over } 3 \text { years } \\
\text { Kept replacement rate at } 60 \% \\
\text { of prior wage }\end{array}$ & $\begin{array}{l}\text { Share of unemployed with no } \\
\text { provision increased } \\
\text { Poverty rate increased, } \\
\text { especially for non-employed } \\
\text { households and for children } \\
\text { Quality of employee-job match } \\
\text { likely to have declined (less time } \\
\text { for search) } \\
\text { Labour supply effect is modest }\end{array}$ \\
\hline
\end{tabular}




\subsection{Case Study 1: Public Works or Workfare Ideology}

\subsubsection{A 'Workfare’ Ideology}

The reform of the social assistance system was high on the agenda of the Conservative Fideszled government. Though they renamedthe unemployment assistance scheme, ${ }^{25}$ in many respects they continued the policy line of their Socialist predecessor, and indeed the strategy of their own first government in 1998-2002 (also led by Viktor Orbán). The first measures concerned the work test: for both unemployment insurance and unemployment assistance recipients, the definition of a suitable job offer was extended to cover jobs requiring skills below the recipient's education (or their last job) and centralised the public works scheme in order to be able to enforce the work test condition on unemployment assistance. The new public works scheme united the formerly separate three schemes run by the central government, local job centres and municipalities, respectively, and placed it under the control of the Interior Ministry. In the new system, job centres refer job seekers to public works schemes and reimburse municipalities implementing local projects approved by the Ministry.

The ideology of 'workfare' was incorporated into the new Fundamental Law (2011), reflecting its importance to the current government. Article XII (1) states that 'every person shall be obliged to contribute to the enrichment of the community to their best ability and potential'. Article XIX (1) limits social rights to a 'set of risks', including unemployment, but only in case it was 'not caused by citizens' own actions'. Furthermore, '[ $t$ ]he nature and extent of social subsidies are to be determined according to the usefulness of the beneficiaries' activities for the community.' Since the acceptance of the Fundamental Law in April 2011, citizens are entitled to social rights only if they fulfil their work responsibilities, a measure that excludes the 'idle poor' from social rights (Kovács 2012; Szikra 2014).

\subsubsection{Public Works Minimum Wage}

In a second wave of changes, a 'public works minimum wage' was introduced in September 2011, which equalled 70 per cent of the national minimum wage, and was to be paid out in weekly, rather than monthly instalments. ${ }^{26}$ Taking effect on the same date, the duration of the UI scheme was cut to an unprecedentedly short 90 days, its ceiling reduced to the minimum wage and the prior contribution requirement increased to 360 days over 3 years.

Municipalities were encouraged to increase the share of part-time (four hours a day) public works contracts, which increased to over two thirds during $2011 .{ }^{27}$ The wage cut and the drop in working time led to a steep fall of income from public works so that it barely exceeded UA. This was corrected in 2012, when the share of part-time employment fell to 6 per cent. This, however, required considerable resources: government spending on public works doubled from 0.21 per cent of GDP in 2011 to 0.46 per cent in 2012 and further increasedto 0.53 per cent in 2013.

The sanctions on failing the work test were also made stricter. Unemployment assistance recipients are obliged to prove 30 days of employment on public works or community work 
(for example, in an NGO) and those who fail this criterion can be excluded from social assistance for up to 12 months. ${ }^{28}$ Refusal to accept an offer of a job, or placement in an ALMP results in removal from the unemployment register for 60 days and exclusion from any social assistance for that period.

The latest measures introduced in 2012 further tightened the unemployment assistance scheme by cutting its nominal level (from about 20 to 15 per cent of the average wage), though it had already lost much of its value in real terms as it had not been uprated since 2008. Also, the remit of local governments was extended to set further behavioural conditions on receiving assistance, such as keeping a tidy house and backyard.

\subsubsection{Political Motivations on the part of both Municipal and Central Authorities}

The apparently growing political demand for regulating the unemployed may have originated from various sources and there is little systematic research on it so far. A list of possible factors may include government failure in tackling long-term unemployment, public opinion maintaining the work ethic of the Socialist era, local tensions arising from long-term unemployment and the lack of capacity in local municipalities to tackle it, and last but not least, the revival of the Conservative political tradition of workfare.

The Conservative government enacted a comprehensive 'welfare to work' reform in 1999. The government's programme for 1998-2002 underlined the need to reduce state redistribution and costly means-tested welfare systems, and support self-help (FIDESZ 1998: 5). According to official rhetoric, the programme was justified by the need to support people who are willing to help themselves and the government's responsibility to safeguard the interests of the tax paying citizen (FIDESZ 1998: 3; Lakner 2005).

A similar, but more radical 'work-based regime' was announced by Prime Minister Orbán soon after electoral victory in 2010, according to which as many as one million new jobs would be created within ten years. ${ }^{29}$ The 'Hungarian Work Plan' [Magyar Munkaterv], introduced in May 2011, was partly copied from the so-called 'National Work Plan' [Nemzeti Munkaterv] of the early 1930s which was designed to boost heavy industry and introduce 'work instead of welfare' (Nemzeti Munkaterv 1932). ${ }^{30}$ This time, in order to 'increase efficiency of implementation', the administration of the programme was moved to the Ministry of Interior, similarly to social policy programmes in the 1930s and 1940s, a fact proudly acknowledged by the Minister himself (Fekete 2011).

The Socialist government evidently acted on different motivations. As already noted, the extension of unemployment assistance into a minimum income scheme was effective in reducing poverty, and especially child poverty, but also raised concerns about widening the unemployment trap. This generated tensions in some municipalities, where officials considered the provision too generous, in some cases based on prejudice against large Roma families. ${ }^{31}$ It was in response to their disapproval that the allowance was capped in December 2006, fixing its maximum level equal to the minimum wage (Firle and Szabó 2007).

In some interpretations, the Socialists' retraction regarding public works schemes was also a backlash against the generous unemployment assistance of 2006. In this reading, the reform 
of 2009 was a political deal with the powerful lobby of mayors. ${ }^{32}$ In return for their consent to the austerity measures made necessary by the global crisis, mayors were allowed to use the Unemployment Assistance for regulating the (idle) poor and especially the Roma, and for filling gaps in their budgets via public works funds, which were not closely scrutinised by the central government. The tightening may have also served to appease the growing public discontent over the inefficiency of Roma integration policies (and a gloomy economic prospect) and to prevent the further growth of support for the far-right (Scharle 2011). ${ }^{33}$ Some argue that the increasingly harsh rhetoric of Fidesz on public works serves the same purpose, i.e. to tease voters away from the extreme right wing Party (Jobbik), by fuelling anti-Roma and anti-poor sentiments (Gall 2013).

Material interests may also play a role. Public works provide mayors and local entrepreneurs with access to cheap labour to do communal work, renovate roads and build gutters. There is anecdotal evidence of public workers who have been ordered to cultivate the lands of the local bosses, harvest their crops or renovate their houses (for example, Tanács 2012). The replacement of civil servants by cheaper and far less protected public workers has also become widespread: schools and even emergency services have been reported to have fired public employees while taking on public workers (Alapvető Jogok Biztosa 2012). Recent research indicates that the organizers of public work programmes (overwhelmingly municipalities) rank 'access to cheap labour' in the first place when asked about the use of such schemes (Koltai and Kulinyi 2013). ${ }^{34}$

Lastly, the current government may seek to use public works in order to conceal its inability to raise the level of employment, since public workers count as employees in the official statistics. The government has indeed communicated the recently observed improvement in the employment rate as confirming the success of their economic and welfare policies, even though several experts pointed out that public workers and cross-border commuters explain much of this 'success' (e.g. Cseres-Gergely et al. 2013).

\subsubsection{Gap between Rules and Implementation}

The negative effects of workfare reforms have been aggravated by their inappropriate design and implementation, including the lack of well-designed incentives for the institutions responsible for administering benefits and especially the public works schemes, a lack of adequate institutional capacity, and perhaps most importantly an almost complete lack of monitoring and supervision on the part of the central government.

An early example for this implementation gap is the merger of unemployment assistance and social assistance in 2000, which entailed the devolution of the administration of the new unemployment assistance to local governments, who were reimbursed by the central government for most of their expenditure on it. The fact that dedicated grants could not be used for other purposes (Semjén 1996) created a disincentive for local governments to strictly enforce job search regulations for unemployment assistance. In addition, many municipalities (especially in villages) merely paid out benefits, lacking the adequate expertise for the provision of genuine employment-oriented assistance to the long-term unemployed. One year 
after the introduction of the new work test, half of all municipalities had not organized public works at all, which was mostly due to the lack of administrative and managerial capacity (Fazekas 2001). On the other hand, larger municipalities benefited from the reform as it provided a new source of funding for public works and extended the eligible types of work to any activity that 'served public interest.'

Research on municipal practices in the implementation of public works schemes during the past decade found large variations in terms of the recruitment of workers, the enforcement of sanctions, the involvement of municipal institutions and the share of part-timers (Fazekas and Köllő 2001; Bódis and Nagy 2008). Local practice tended to depend on whether the mayor interpreted the main goal of public works to be poverty reduction, activation of the unemployed, easing tensions between the unemployed and the working poor or simply as an extension of their budget. Recent research on the current scheme suggests that such variations have tended to prevail (Koltai and Kulinyi 2013).

The lack of monitoring may lead not only to corruption but also to excesses and arbitrary interpretations of the law, which may hinder access to benefits both directly and indirectly, by increasing the stigma of benefit receipt. One example is a practice recently invented by some municipalities to levy fines on benefit recipients and then deduct any due payments from their wages when they work on a public works scheme. As a result, those indebted with communal payments might see only a fraction of their salary at the end of the week (Állampolgári Jogok Biztosa 2012).

\subsubsection{Discriminatory Practices}

Furthermore, as local governments are not obliged to organize public works for all the unemployed in their area, many people fail to meet the requirement of 30-days attendance in such programmes, and this automatically excludes them from any form of social assistance for at least two months. This loophole is blatantly used by some racist mayors to exclude the Roma from this programme. ${ }^{35} \mathrm{~A}$ human rights watchdog regularly reports from villages run by the extreme right-wing party Jobbik; it claims that the Roma are not given enough information about public works programmes and are often employed in extremely humiliating conditions if they are included. ${ }^{36}$

\subsubsection{Impact of the Changes}

The frequent and radical changes in the legislation, as well as the complexity of the rules make it more difficult for the unemployed to understand their legal standing and seek legal remedy.

Cutting the nominal level of unemployment assistance and linking it more closely to the extended public works programme, as well as other behavioural conditions has increased the vulnerability of the long-term unemployed during the crisis years. This has been aggravated by implementation problems and increasing political tensions, which are both closely linked to the increasing ethnic dimension of poverty and unemployment. 


\subsubsection{What Outcomes on Long-term Unemployment, Labour Supply and Social Inclusion?}

To date, no systematic evaluation of the effects of the post-2010 public works programme is available in terms of labour market outcomes and social inclusion. Earlier research indicates that long-term unemployment slightly increased in villages with extensive public works programmes (Köllö and Scharle 2011). The programme is especially inefficient in comparison with training and education schemes (Csoba and Nagy 2012).

A recent survey shows that the large majority of public workers ( 73 percent) carry out physical work that requires primary education and no skills. While 46 per cent of them have completed secondary school, only 15.3 per cent are engaged in activities requiring such qualifications (Koltai and Kulinyi 2013: 48). This points to a lack of possibilities to increase or even to maintain existing skills and qualifications in the public works programme, which decreases chances of future employment. Public work organizers themselves do not find future employment as an important aim of the programme: 51 per cent of employers did not believe that public works would contribute to the re-employment of participants in the regular labour market (ibid: 54$){ }^{37}$

The long-term unemployed and among them the Roma minority in remote areas seem to be the greatest losers of the reform of the unemployment assistance as it increases the possibility of arbitrary decisions by local mayors over their inclusion in or exclusion from the social assistance system without the possibility of any legal remedy (Állampolgári Jogok Biztosa 2012; Vidra 2012). Research also indicates that women and people with weak physical abilities have significantly fewer public works opportunities than 'healthy' ones, which suggests that the most vulnerable are excluded from the programme (Állampolgári Jogok Biztosa 2012; Koltai and Kuliny 2013: 53).

As already mentioned, social and economic policies at the end of the decade increased inequalities. The freezing of the universal child benefit and the decreasing of means-tested unemployment assistance has played an important role in the increase of poverty (from 13.6 in 2009 to 17 per cent in 2012) and the increased deprivation not only of the poorest but also of the lower middle class. For example, properly heating their homes during winter was a problem for 20 per cent of Hungarians in 2009 and 27 per cent in 2012 (Szívós and Tóth 2013: 47). An alarmingly high share -44 per cent - of children live in households with multiple deprivation (ibid.).

The nominal decrease in unemployment assistance in 2010, the tightening of sanctions on non-compliance in 2011 and the reduction in ALMP spending further decreased the chances of breaking out of deep poverty and desperate labour market conditions in the poorest regions of Hungary. Recent research conducted in 35 small settlements that are among the poorest in Hungary indicates that disintegration and distrust increased even in villages where mayors try to soften the effects of anti-poor policies (Vidra 2013: 79). The supportive networks of the long-term unemployed, and among them especially women, seem to have narrowed radically, while violence and mental illness have become widespread (Czibere 2012; Kotics 2012: 62). 


\subsubsection{Concluding Remarks and Policy Recommendations}

Even within the current political constraints, it could be possible to put into place a transparent and effective mechanism for uprating the level of social assistance (and that of the wage paid in related workfare programmes) which would prevent its automatic loss of purchasing power due to inflation. The issue of paying the statutory minimum wage in workfare programmes should also be raised. Increasing the amount of the housing allowance (and implementing an automatic mechanism for its uprating) or the child benefit (családi pótlék) are other - and possibly, politically more feasible - ways of bringing the income of the poorest households closer to what is necessary to live in a manner compatible with human dignity.

Take-up as well as equitable participation in workfare programmes could be improved if job centres cooperated with social work agencies and received guidance on referring clients to these programmes and if the level of non-take-up, sanctioning and discrimination were regularly monitored. Further improvement could be achieved by making due process appeal available to those who have been excluded from social assistance or workfare because of an assumed violation of behavioural conditions. Corrective measures may also extend to an easing of the definition of a suitable job and abolishing all behavioural conditions not related to availability for work or employability, but prone to arbitrary application (for example, the requirement to keep a tidy house).

In the medium term more should be done to improve take-up and adequacy of social assistance. The current scheme should be replaced with a single top-up scheme which is proportional to household incomes, the level of minimum income should be significantly raised and be uprated annually, and made available to the working poor. Sanctions on failing to meet behavioural conditions should be eased, while the quality and accessibility of active labour market measures should be improved. Rather than keeping the benefit level low or stopping it altogether for non-compliance with behavioural conditions, there should be fine-tuned withdrawal rules to reduce the poverty trap and labour supply disincentives.

\subsection{Case Study 2: Unemployment Insurance - Unprecedented Cuts and Labour Supply Effects}

\subsubsection{Sharp Drop in Coverage}

The coverage of insured unemployment benefit was relatively stable until the financial crisis. It fell from around 30 per cent to 10 per cent following the drastic cut in the duration of the unemployment insurance scheme in late 2011. Figure 6.2 shows benefit receipt in proportion to the combined pool of registered unemployed and those employed on public works. The cut in unemployment insurance also increased the share of registered jobseekers receiving no financial assistance from around one-third to almost half. 
Figure 6.2 Unemployment benefit receipt and participation in public works, Hungary,

2000-2012

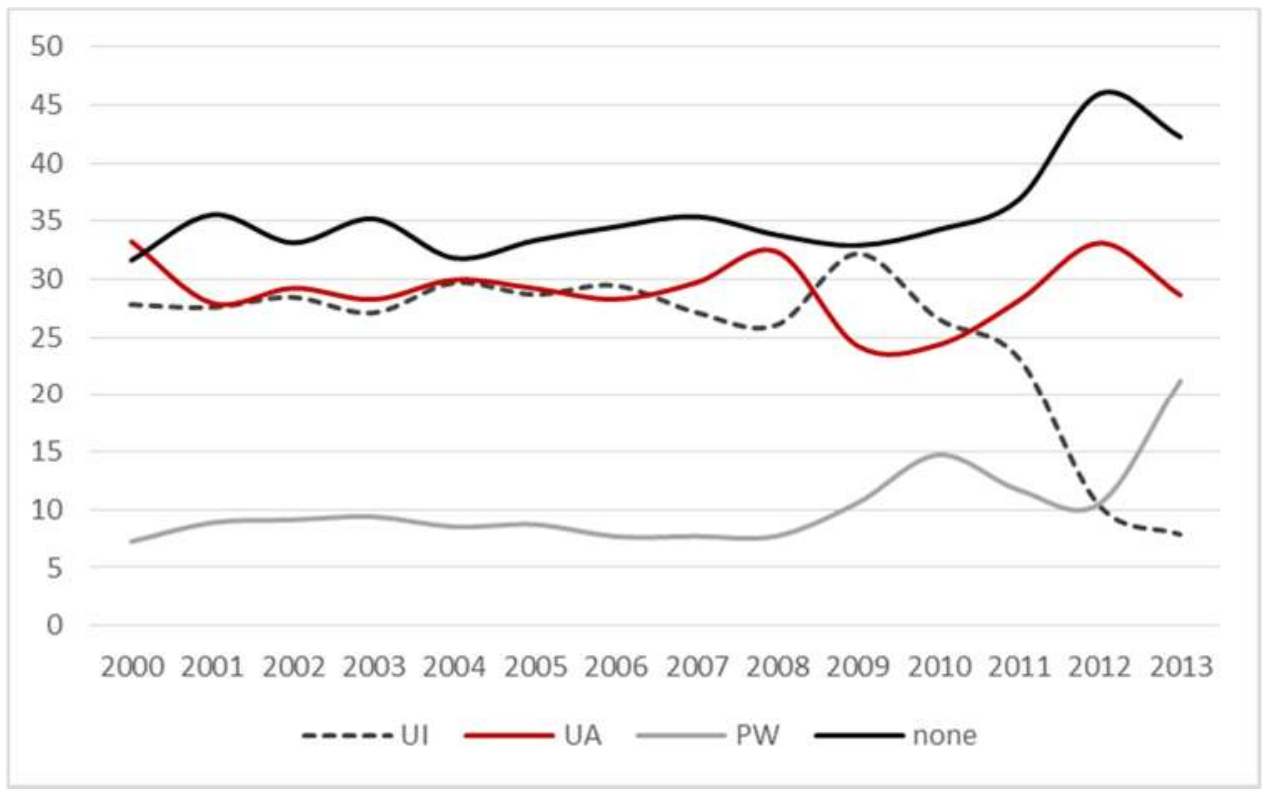

Note: $\mathrm{PW}=$ public works participants. Annual averages

Source: Authors' calculations based on National Labour Office (NLO) data.

The main objective of the cut was to strengthen labour supply incentives, which it achieved to some extent, but at the expense of increasing poverty, and most likely a deterioration in the efficiency of matching workers and jobs. The next section briefly reviews the arguments behind extending benefit duration at times of crisis, and the rest of the case study summarizes empirical evidence on the labour supply effects of unemployment insurance cuts in Hungary. Results pertaining to the most recent cut are very preliminary.

\subsubsection{Arguments for State Insurance for Unemployment and Optimal Length}

The literature on the optimum duration of unemployment provision as well as current practice in developed countries suggests that the entitlement period is far too short in Hungary (see, for example, Landais et al. 2011). ${ }^{38}$

Unemployment benefits may keep the reservation wage higher than optimal, and thus can increase the period of unemployment, but at the same time benefits help job seekers find the position most suited to their abilities, thus making the worker-employer match more effective. ${ }^{39}$ Besides solidarity, this is the strongest argument for mandatory state unemployment insurance. This is because such insurance would not work on a market basis, while it is the only way to ensure that workers who lack the savings to support a family and themselves can still search for a new job with the appropriate care. Benefit payments also make sense even if the problem could be tackled by taking out a loan, because many people cannot realistically assess their future opportunities or are unable to secure an adequate loan due to a dysfunction in the capital markets. 
Lastly, unemployment provisions (if they smooth consumption) act as automatic stabilizers during times of economic recession as they automatically increase government spending and consumption and thus mitigate fluctuations in the economy (see, for example, Auerbach and Feenberg 2000).

\subsubsection{The Labour Supply Effect}

The expectation was that the recent cut of the duration of unemployment insurance would be deep enough to induce a significant labour supply response. Did that take place?

In the past twenty years, nine empirical studies have examined the impact of the repeated cuts in the insurance-based unemployment benefit or the allowance for the long-term unemployed, and neither of them found a substantial positive effect on labour supply. In a study examining the reduction of unemployment insurance in 1993, Micklewright and Nagy (1999) find a sudden increase in the re-employment rate of claimants immediately after they exhausted the benefit - suggesting that some of them found a job earlier, but delayed re-entry - but the affected group is only 2-3 per cent of the cohort under analysis. Wolff (2001), the most prudent of the three studies dealing with the reform of 1993, finds no effect of a combined decrease in the replacement rate (the benefit divided by the previous wage) and in the benefit duration in the case of men, and only a minor positive effect in the case of women.

There are no similarly detailed studies available on the most recent cut. The aggregate statistics published by the NLO on unemployment insurance recipients show first that the educational composition of the registered unemployed (not unemployment insurance entrants but the stock of all registered unemployed) is relatively stable and that the registered stock was declining in the few months preceding the policy change. Assuming that the economic environment was roughly the same in 2010 and 2011, a comparison of monthly exit rates should also reveal the labour supply effect of the cut in the benefit duration. The figures presented in Table 6.6 indeed show a positive effect after November, which is when the benefit expired for the first entrants into the new scheme.

Table 6.6 Registered unemployed and exits from UI, Hungary, July-December 2011

\begin{tabular}{|l|c|c|c|c|c|c|c|}
\hline & $\begin{array}{c}\text { Registered } \\
\text { unemployed }\end{array}$ & $\begin{array}{c}\text { Primary } \\
\text { education \% }\end{array}$ & UI recipient & Exit to job & \multicolumn{2}{|c|}{ Exit to job, \% } & $\begin{array}{c}\text { Difference } \\
\text { in exit rate }\end{array}$ \\
\hline July & 2011 & 2011 & 2011 & 2011 & 2011 & 2010 & \\
\hline August & 554,207 & 39.1 & 101284 & 9276 & 0.092 & 0.092 & 0.000 \\
\hline September & 538,956 & 39.1 & 101490 & 8562 & 0.084 & 0.087 & -0.002 \\
\hline October & 530,763 & 40.1 & 96462 & 9734 & 0.101 & 0.093 & 0.007 \\
\hline November & 526,283 & 40.2 & 94894 & 7707 & 0.081 & 0.078 & 0.003 \\
\hline December & 552,308 & 40.6 & 97964 & 7374 & 0.075 & 0.059 & 0.016 \\
\hline
\end{tabular}

Note: Exits include those who left the unemployment register because of entering a job.

Source: NLO on-line statistics (www.munka.hu). 
Adamecz et al. (2013) take a sample of jobseekers entering the unemployment register between August and October 2011 and examine their labour market outcomes from their entry to the register until May 2013. Entrants to the register before 1 September 2011 were still eligible for 270 days of unemployment insurance, while those entering after that date were eligible for the benefit for 90 days only. If entrants in August and September are the same in terms of age, gender, prior employment history and place of residence, any difference in their reemployment probabilities can be attributed to the reduction in the benefit duration. Observable differences in their composition can be controlled for by regression analysis, so that the only remaining bias in the estimates will be due to unobserved characteristics, such as motivation. Their first results suggest that those with a shorter benefit entitlement have a higher probability to be reemployed than their otherwise similar peers who are still entitled to 9 months of unemployment insurance. The effects are significant for both men and women, and vary with level of education. There is some concern, however, that the estimates are biased due to seasonality in job entries and unobserved differences in the composition of the treatment and control groups.

\subsubsection{Concluding Remarks}

Although the main objective of the cut in the duration of unemployment insurance was to strengthen labour supply incentives, it is also important to consider the unintended side effects of this measure. The social impact of the cut is undoubtedly negative: few jobseekers can get reemployed within three months and those who remain unemployed are now left with the flat rate social assistance, which is considerably below their previous earnings, or nothing, if their household income is above the social assistance threshold (set below the upper bound of the bottom income decile). This is likely to hurt especially the lower middle class who may not have sufficient savings to bridge a long unemployment spell, and especially those who were also affected by the sudden deterioration of the exchange rate which doubled or tripled their mortgage payments. ${ }^{40}$

The economic impact - beyond labour supply - is also likely to be negative, as the pressure on jobseekers to get back into employment tends to reduce the efficiency of matching workers and jobs.

\section{CONCLUSIONS}

Changes to the Hungarian welfare system since 2000 have been mixed but mainly contribute to a weakening of the European Social Model as transposed in Hungary. Workers' rights and especially consultation tended to improve gradually up to 2006 and have deteriorated since then. This negative trend accelerated after the elections in 2010, and with the new Labour Code of 2011. Similarly, the availability and generosity of welfare provisions tended to increase until 2006 and decline afterwards. At first, cuts focused mainly on unemployment benefits and social 
assistance, which only led to increasing poverty, with little impact on employment. Later measures affected early pensions and disability benefits as well, which could have contributed to correcting the structural distortions of the labour market. However, with limited efforts to encourage labour demand in the meantime, employment effects remained modest. Coupled with a tax reform favouring high income families in 2011, the cuts resulted in growing inequalities and poverty. The promotion of equal opportunities shows a slightly different pattern: the general trend has been of gradual improvements in legislation with little change in practice. Most recent developments diverge across target groups: while support for Roma integration has decidedly decreased and gender equality institutions substantially weakened, developments have been mixed in the case of disabled jobseekers.

An overall assessment of recent changes reveals a bleak picture. The economic policy of the new government strategy is seriously flawed, with internal inconsistencies in both the plan and its implementation. Measures are implemented in an authoritarian manner, which reduces their effectiveness and delays recovery. While the quality of government measures is reduced by the lack of consultation, their impact is further constrained by a general lack of stability and predictability in the business environment. All of this has grave consequences for labour market prospects, poverty and social inclusion.

Most of the recent changes are not irreversible, however (Table 6.7). Consultative institutions, provisions for the unemployed and equal rights institutions can be reinstated relatively easily. Some measures need not be fully reversed but slightly adjusted or supplemented with supporting initiatives. The renationalization of the private pension pillar is perhaps the only major change that cannot be undone, or only at a high cost. It must also be noted that the feasible adjustments, while each of them are manageable on their own, together add up to a major reform, requiring trust in government as well as a public administration with much stronger capacities and competence than are currently available.

Table 6.7 How reversible are the recent changes in Hungary?

\begin{tabular}{|l|l|l|l|}
\hline & Rights and consultation & Welfare & Equal opportunities \\
\hline $\begin{array}{l}\text { Should and can be } \\
\text { reversed }\end{array}$ & Consultative institutions & $\begin{array}{l}\text { Duration of } \\
\text { unemployment benefits, } \\
\text { spending on public } \\
\text { works, amount of } \\
\text { unemployment } \\
\text { assistance, PES staff }\end{array}$ & $\begin{array}{l}\text { Separate PES for } \\
\text { disabled, ombudsman, } \\
\text { school segregation, } \\
\text { school age }\end{array}$ \\
\hline $\begin{array}{l}\text { Does not need to be } \\
\text { reversed but should } \\
\text { be adjusted }\end{array}$ & $\begin{array}{l}\text { Employees' rights, } \\
\text { minimum wage }\end{array}$ & $\begin{array}{l}\text { Early pensions, } \\
\text { disability benefits }\end{array}$ & $\begin{array}{l}\text { Maternity benefits, } \\
\text { compulsory } \\
\text { kindergarten }\end{array}$ \\
\hline $\begin{array}{l}\text { Difficult to reverse } \\
\text { but needs to be } \\
\text { adjusted at least }\end{array}$ & Private pension pillar & \\
\hline
\end{tabular}


Any new government intending to restore the ESM will thus be forced to prioritize and sequence their measures over several years. We recommend two areas that should enjoy priority. One is to re-establish consultative institutions in order to build trust and to ensure that relevant stakeholders and experts are included in working out the later steps of the reform. The other is to increase the amount of and to ensure equal access to social assistance in order to prevent a further increase in poverty and inequalities.

\section{BIBLIOGRAPHY}

Adamecz, A., Márk, L., Scharle, Á. (2013), Estimating the labour supply impact of a large cut the duration of insured unemployment benefit, Manuscript. January 2014.

Alapvetö Jogok Biztosa (Ombudsman of Fundamental Rights) (2012), Report of the Ombudsman on the Case AJB-3025/2012. Budapest: Office of the Commissioner of Fundamental Rights (in Hungarian).

Altwicker-Hámori, S. and Köllő, J. (2013), 'Hungary: Public Sector Labour Market from Crisis to Crisis', in: Vaughan-Whitehead, D. (ed.): Public Sector Shock. The Impact of Policy Retrenchment in Europe, Cheltenham: Edward Elgar. 300-336.

Amerikai Népszava (2011) 'The Programme of Gömbös is being Implemented by Orbán', Amerikai Népszava Online, 25 July, available at http://nepszava.com/ 2011/07/magyarorszag/gombos-gyula-programjat-valositjak-meg-orbanek.html (in Hungarian). (Retrieved December 31, 2013)

Antal, L. (2000), ‘A Bokros-csomag', in: Beszélö, 6. Vol. 5. No. 6: 82-91.

ÁSZ (2004), 'Jelentés a Munkerőpiaci Alap müködésének ellenőrzéséről.' Állami Számvevőszék [Report on the Monitoring of the Labour Market Fund's Operation] Budapest:, Budapest.

Auerbach, A.-Feenberg, D. (2000), The significance of federal taxes as automatic stabilizers. Journal of Economic Perspectives, Vol. 14, No. 3. 37-56.

Augusztinovics, M., Gál, R. I., Matits, Á., Máté, L., Simonovits, A. and Stahl, J. (2002), 'The Hungarian pension system before and after the 1998 reform.' In Fultz, E. (ed.), Pension Reform in Central and Eastern Europe, Vol. 1-2, Geneva: International Labour Office. 2594.

Bálint, M. (ed.) (2012): Statistical data. In: The Hungarian Labour Market. Review and Analysis, Budapest: Institute of Economics, Hungarian Academy of Sciences, 321-400.

Bálint, M. and Köllő, J. (2008), ‘A gyermekgondozási támogatások munkaerőpiaci hatásai’ [Labour market effects of parental leaves.] In Esély, 2008.1. 1-21.

Bálint, M., Cseres-Gergely, Zs., and Scharle, Á. (2011), The Hungarian labour market in 20092010. In: Fazekas and Molnár (2011): The Hungarian Labour Market. Review and Analysis. Budapest: Institute of Economics, Hungarian Academy of Sciences, 15-36. 
Balla, K., Köllö, J. and Simonovits, A. (2008), 'Transition with heterogeneous labour'. In: Structural Change and Economic Dynamics, Vol. 19. No. 3: 203-220.

Bartha, A. (2012), The macroeconomic and business environment, in Fazekas and Scharle (ed.), From Pensions to Public works. Hungarian Employment Policy from 1990 to 2010, Budapest Institute and IE-HAS, Budapest.

Benczúr, P., Kátay, G., Kiss, Á., Reizer, B. and Szoboszlai, M. (2011), Analysis of changes in the tax and transfer system with a behavioural microsimulation model, MNB Bulletin, October 2011. Budapest: National Bank of Hungary.

Benedek, D., Firle, R. and Scharle, Á. (2006), 'Degree and efficiency of redistribution', Working Papers in Public Finance, 16, Hungarian Ministry of Finance, August 2006

Benedek, D., Lelkes, O., Scharle, A. and Szabó, M. (2004), 'The structure of general government expenditure and revenues in Hungary, 1991-2002', Working Papers in Public Finance, 9, Hungarian Ministry of Finance, August 2004.

Bertelsmann Stiftung (2012), Hungary - Country Report. Gütersloh: Bertelsmann Stiftung.

Blanchard, O. (1998) The Economics of Post Communist Transition, Oxford: Oxford University Press.

Bódis, L. (2012), Organisational capacity, organisational learning. In: Fazekas and Scharle (eds), From Pensions to Public Works. Hungarian Employment Policy from 1990 to 2010, Budapest Institute and Institute of Economics, HAS, Budapest.

Bohle, D. and Greskovits, B. (2012), Capitalist Diversity on Europe's Periphery, Cornell University Press, Ithaca.

Bódis, L. and Nagy, G. (2008), Empirikus vizsgálatok a munkanélküli ellátások magatartási elöírásainak ellenőrzéséről, Kormányzás, Közpénzügyek, Szabályozás, 3, 1, 39-47.

Budapest Institute (2008), The impact of policies to promote the employment of older workers: a preliminary assessment, Budapest Institute.

Budapest Institute (2012), Evaluation of the first phase of flexicurity 2007-2010: Country case study report - Hungary, April 2012, Report for GHK Consulting.

Bugarszki, Zs. (2004), 'A szociális szolgáltatások újjászületése Magyarországon.' [The renessaince of social services in Hungary] Esély, 2004/4., 100-110

Bugarszki, Zs. (2006), 'A közösségi pszichiátriai ellátásról. Néhány gondolat egy új szolgáltatáshoz.' [On community mental health care. Notes on a new service], in: Esély, 2006/1. 67-73.

Cerami, A. (2009), 'Socio-Economic Transformations in Post-Communist Countries: Central and Eastern Europe and Russia Compared.' In. Romanian Journal of Political Science, vol. 9. no. 1 .

Csemniczki, K. (2000), 'Nyugdíjrendszerünk 1929-től 1997-ig.' [The Hungarian pension system from 1929 to 1997] In: Augusztinovics, M. (szerk.): Körkép reform után. Tanulmányok a nyugdíjrendszerröl. Közgazdasági Szemle Alapítvány, Budapest., 28-50.

Cseres-Gergely, Zs. and Scharle, A. (2008), 'Social welfare provision, labour supply effects and policy making', in: The Hungarian Labour Market. Review and Analysis, Budapest: Institute of Economics, HAS, 33-49. 
Cseres-Gergely, Zs., Kátay, G. and Szörfi, B. (2013), 'The Hungarian labour market in 20112012'. In: Fazekas, K. et al. (eds), The Hungarian Labour Market. Institute of Economics,HAS, Budapest, 18-40.

Csoba, J. and Nagy, Z.É. (2012), The Evaluation of Training, Wage Subsidy and Public Works Programs in Hungary, In: The Hungarian Labour Market 2012. Institute of Economics,HAS, Budapest, 96-122.

Czibere, I. (2012), Nők mélyszegénységben. Személyes életvilágok és cselekvési perspektívák a mélyszegénységben élö nők mindennapjaiban. [Women in extreme poverty. Personal circumstances and options in the everyday lives of women in extreme poverty.]

.L'Harmattan, Debreceni Egyetem, Budapest.

Drahokoupil, J. and Domonkos, S. (2012), 'Averting the funding-gap crisis: East-European pension reforms since 2008,' Global Social Policy 12(3): 283-299.

Duman, A. and Scharle, Á. (2011), 'Hungary: fiscal pressures and rising resentment against the (idle) poor.' In: Clasen, J. and Clegg, D. (eds), Regulating the Risk of Unemployment. National Adaptations to Post-Industrial Labour Markets in Europe. Oxford University Press, pp. 232-255.

Economic Intelligence Unit (2011), Democracy index 2011: Democracy under stress. Available at:

http://www.eiu.com/public/topical_report.aspx?campaignid=DemocracyIndex2011

(Retrieved December 31, 2013)

Elek, P. and Scharle, Á. (2011), 'Crisis measures in the labour market.' In. Fazekas, K. Molnár, Gy. (eds), The Hungarian Labour Market. Review and Analysis, Institute of Economics, Hungarian Academy of Sciences andNational Employment Foundation, Budapest.

European Parliament (2013), Report on the situation of fundamental rights: standards and practices in Hungary. (Pursuant to the European Parliament resolution of 16 February 2012). Committee on Civil Liberties, Justice and Home Affairs. Brussels. 24.6.2013

European Women's Lobby (2012), Ticking Clocks. Alternative 2012 Recommendations to Strengthen Women's Rights and Gender Equality in the Europe 2020 Strategy . Brussels. Creative Commons and European Women's Lobby

Eurostat (2013) General Government Gross Dept. http:/epp.eurostat.ec.europa.eu/portal/page/portal/government finance statistics/data/main tables (Retrieved December 31, 2013)

Fazekas, K. (2001), Az aktív korú allástalanok rendszeres szociális segélyezésével és közcélú foglalkoztatásával kapcsolatos önkormányzati tapasztalatok, [Municipal practices in administering social allowance and public works for the working age unemployed.] Budapest Working Papers on the Labour Market, No. 2001/9.

Fazekas, K. (2002), 'Regional Disparities in Unemployment in the CEE Countries: The Case of Hungary.' In: Pizatti, L. (ed.), Labour, Employment and Social Policies in the EU Enlargement Process: Changing Perspectives and Policy Options, Washington: World Bank, 2002, pp. 176-196.

Fazekas, K. and Scharle, Á. (eds) (2012), From Pensions to Public Works. Hungarian Employment Policy from 1990-2010, Budapest Institute and IE-HAS, Budapest. 
Fazekas, K., Benczúr, P. and Telegdy, Á. (2013), The Hungarian Labour Market 2013, HAS - NENPC, Budapest 2013.

Fekete, G.A. (2011) 'We Won't Build Tin-cities: Interview with the Minister of Interior, Sándor Pintér', Népszabadság, 21 July, available at http://nol.hu/belfold/20110721_nem_epitunk_bado-gvarosokat_-1143411 (in Hungarian). (Retrieved December 31, 2013)

Fidesz Magyar Polgári Párt (1998), A Fidesz Magyar Polgári Párt Programja - 48 pont [The Programme of FIDESZ-Hungarian Civic Alliance - 48 points], Fidesz MPP, Budapest.

Firle, R. and Szabó, P.A. (2007), Targeting and labour supply effect of the regular social assistance, Working Papers in Public Finance, No.18.: Eötvös Loránd University, Faculty of Social Sciences.

Frey, M. (2001), Jogszabályok és intézmények, [Laws and institutions] In: Munkaerőpiaci Tükör, Budapest: Institute of Economics, Hungarian Academy of Sciences, 179-197.

Frey, M. (2006) Changes in the legal and institutional environment of the labour market, In: The Hungarian Labour Market, Budapest: Institute of Economics, Hungarian Academy of Sciences

Gall, L. (2013) 'Hungary's Alarming Climate of Intolerance', CNN, 18 January. (Retrieved December 31, 2013)

GHK (2012), Evaluation of flexicurity 2007-2010: Final Report, October 2012.

Galasi Péter (1996), A munkanélküliek álláskeresési magatartása [Job search behaviour of the unemployed], In: Közgazdasági Szemle, 43.9, 805-815.

Guardiancich, I. (2013), Pension Reforms in Central, Eastern and Southeastern Europe: From Post-Socialist Transition to the Global Financial Crisis, Routledge/EUI.

GWI (2013), Feminism and Gender Democracy, Gunda Werner Institute. Available at: http://www.gwi-boell.de/web/eu-countries-comparison-gender-politics-policy-hungary-3561.html (Retrieved December 31, 2013)

HCLU, Hungarian Civil Liberties Union (2013), 'Hungarian Government Creates Legal Framework for Segregating Rome children in Schools.' Available at: http://tasz.hu/en/romaprogram/hungarian-government-creates-legal-frameworksegregating-roma-children-schools (Retrieved December 31, 2013)

Fink et al. (2011), Study on Flexicurity: Measuring the impact of flexicurity policies on the EU labour market, Report on a research project commissioned by the European Commssion, DG EMPL, 2 Volumes, Vienna: Institute for Advanced Studies (IHS), 1 June 2011.

Horváth, Sz. (2006), 'Politikai valóság a Heti Válaszban. Ellenfél és identitáskonstrukciók a 2002-es valasztasok előtt' [Political Reality in Heti Válasz. Opponent and identity constructions in the run-up to the 2002 elections], in Szabó, M. (ed.), Fideszvalóság, Budapest: L'Harmattan, pp. 161-182.

Hungarian Central Statistical Office - HCSO (2012) 'A bruttó hazai termék (GDP) értéke és volumenindexei (1991-)' Table 2.1.1. 3.1.1. [The value and index of gross national product.] (Retrieved December 31, 2013)

IE HAS (2002): The Hungarian Labour Market: Review and Analysis, Budapest: Institute of Economics, Hungarian Academy of Sciences. 
IE HAS (2008): The Hungarian Labour Market: Review and Analysis, Budapest: Institute of Economics, Hungarian Academy of Sciences.

IE HAS (2013): The Hungarian Labour Market: Review and Analysis, Budapest: Institute of Economics, Hungarian Academy of Sciences.

ILO (2010), World Social Security Report 2010/11. Providing coverage in times of crisis and beyond. Geneva: ILO.

Inglot, T. (2008), Welfare States in East Central Europe, 1919-2004, Cambridge: Cambridge University Press.

Inglot, T., Szikra, D. and Rat, C. (2012) 'Reforming Post-Communist Welfare States. Family Policy in Poland, Hungary and Romania since 2000.' Problems of Post-Communism, vol. 59, no. 6, (November-December 2012), pp. 27-49.

IPU (2013), Women in National Parliaments. Inter- Parliamentary Union. Available at: http://www.ipu.org/wmn-e/classif.htm (Retrieved 1 April 2013.)

Juhász, B. (2012), 'Orbán's politics - a gender perspective', Working Paper, Friedrich Ebert Foundation, Budapest Office, January 2012.

Kátay, G. and Nobilis, B. (2009), Driving Forces Behind Changes in the Aggregate Labour Force Participation in Hungary, MNB Working Papers No 2009/5, available at: http://econpapers.repec.org/paper/mnbwpaper/2009 2f5.htm (Retrieved December 31, 2013)

Kelen, A. (1996), 'Purgatórium vagy regula - A Bokros-csomag és a reformpolitika' [Purgatory or Regulation - The Bokros Package and Reform Policy], Esély, 7/2, 37-44.

Kertesi, G. (2010), 'Roma employment at the turn of the millennium. An analysis of the nationwide representative Roma survey of 2003.' In: Fazekas, K., Lovász, A. and Telegdy, Á. (eds), The Hungarian Labour Market 2010. Budapest, pp. 135-150.

Koltai, L. and Kulinyi, M. (2013), “A közfoglalkoztatók értékei.” [The Values of Public Works Employers], Esély, vol. 5, pp. 38-67,

Köllö, J. (2009), A pálya szélén. Iskolázatlan munkanélküliek a posztszocialista gazdaságban.

[On the margins. Unskilled unemployed in the post-socialist economy.] Osiris, Budapest.

Köllő, J. (2009), Hungary's Failed Attempts at Increasing Maternal Employment, WORKCARE Report. Available at:

www.abdn.ac.uk/socsci/research/nec/workcare/documents/working_paper6 tarki.doc

(Retrieved December 31, 2013)

Köllö, J. (2011), 'Employment, unemployment and wages in the first year of the crisis', in:

Fazekas and Molnár (eds), The Hungarian Labour Market. Review and Analysis. 43-68.

Köllö, J. (2012), 'Hungary: Crisis coupled with a fiscal squeeze - effects on inequality', in VaughanWhitehead, D. (ed.), Work Inequalities in the Crisis: Evidence from Europe, Cheltenham, Northampton: Edvard Elgar Publising 278-313.

Köllö, János and Ágota Scharle (2012), The impact of the expansion of public works programs on long-term unemployment, The Hungarian Labour Market 2012

Kollonay-Lehoczky, Cs. (2012), "Une "troisième voie" en droit du travail? Un panorama du nouveau Code du Travail Hongrois: Entre un libéralisme extrême et des réminiscences de l'économie planifiée centralisée.' ["A "third way" in labour law? An overview of the new 
Hungarian Labour Code: Between extreme liberalism and reminiscences of the centralised planned economy"] In: Comptrasec - Revue de Droit Comparé du Travail et de la Securité Sociale, 2012(2): 76-96.

Kornai, J. (1993), Transformational recession: a general phenomenon examined through the example of Hungary's development, Collegium Budapest Working Paper, No.1.

Körösényi, A. (2012), A politikai polarizáció és következményei a demokratikus elszámoltatásra Magyar politika, 1990-2010 [Political Polarisation and Its Consequences for Democratic Accountability] working papers in political science 2012/1. Available at: http://www.mtapti.hu/pdf/2012_1_wp.pdf (Retrieved December 31, 2013)

Kotits, J. (2012), "'I am to live on this day..." Subsistence strategies of long-term unemployed.' in.: The Consequences of Freezing Social Allowance in Rural Hungary. An Interdisciplinary Documentation. Butterfly Research. Available at: http://www.pillangokutatas.bffd.hu/findings/studies (Retrieved December 31, 2013)

Kovács, K. (2012), 'Equality: The Missing Link.' In. Gábor Attila Tóth (ed.) Constitution for a Disunited Nation. On Hungary's 2011 Fundamental Law. Central European University Press. Budapest - New York. 2012. 171-195.

Laki, M., Nacsa, B. and Neumann, L. (2013), Az új Munka Törvénykönyvének hatása a munkavállalók és a munkáltatók közötti kapcsolatokra [The impacts of the New Hungarian Labour Code on the employee-employed employer relationships]. Available at: http://econ.core.hu/file/download/mtdp/MTDP1302.pdf (Retrieved December 31, 2013)

Lakner, Z. (2005), A megszakitottság folyamatossága. Változó prioritások a rendszerváltás utáni magyar szociálpolitikában. [The continuity of discontinuity. Changing priorities in post-communist Hungarian social policy.] Manuscript. http://www.eselyegyenloseg.hu/download.php?ctag=download\&docID=826. (Retrieved December 31, 2013)

Landais, C.-Michaillat, P.-Saez, E. (2011): Optimal unemployment insurance over the business cycle. National Bureau Of Economic Research, Working Paper, 16526.

Lannert, J. (2004), Strategies for reform and innovation in Hungarian public education, Country note for the 2nd Schooling for Tomorrow Forum held on 6-8 June 2004 in Toronto, Ontario, Canada. Available at: http://www.oecd.org/innovation/research/32506999.PDF (Retrieved December 31, 2013)

Lovász, A. (2008), 'Competition and the Gender Wage Gap: New Evidence from Linked Employer-Employee data in Hungary, 1983-2003'. Budapest Working Paper on the Labour Market. BWP 2008/4. Corvinus University - Hungarian Academy of Sciences, Budapest.

Lovász, A. (2012), 'Labour market discrimination', in Fazekas and Scharle (ed.), From Pensions to Public Works. Hungarian Employment Policy from 1990 to 2010, Budapest Institute and IE-HAS, Budapest.

Majtényi, B. (ed.) (2009), Lejtős Pálya. Antidiszkrimináció és esélyegyenlőség [Slanted field. Antidiscrimination and equality of opportunity.], Budapest: L'Harmattan.

Nagy Gyula - Micklewright, John (1999), Living standards and incentives in transiton: The impications of UI exhaustion in Hungary. Journal of Public Economics 3, 297-319. 
MSAL (2005), Beijing+10 Evaluation of the implementation of the UN World Congress on Women (Beijing, 1995) Platform for action in Hungary. Budapest: Ministry of Social Affairs and Labour

MNB (2011), Labour market institutions in Hungary with a focus on wage and employment flexibility, MNB Occasional papers.

Müller, K. (1999) The Political Economy of Pension Reform in Central-Eastern Europe. Cheltenham, Northampton: Edward Elgar

Nagy, Gy. (2012), 'Using eligibility criteria to stimulate job search', in: Fazekas and Scharle (ed.), From Pensions to Public Works. Hungarian Employment Policy from 1990 to 2010. Budapest: Budapest Institute and IE-HAS, 117-129.

Nagy, K. (ed.) (2013), The effects of reducing the social allowance in rural Hungary, 2012. Interdisciplinary documentation. Pro-Cserehát Association, Budapest.

Nemzeti Munkaterv (National Work Plan), (1932) Budapest: Nemzeti Egység Pártja (in Hungarian).

Neumann, L. and Váradi, B. (2012), 'Wage and taxation policies', in: Fazekas and Scharle (eds), From Pensions to Public Works. Hungarian Employment Policy from 1990 to 2010, Budapest Institute and Institute of Economics HAS, Budapest. pp 32-46.

NGM (2011), Hungary's Structural Reform Programme, 2011-2014. Based on the theses of the Széll Kálmán Plan. Ministry of National Economy Budapest. March, 2011.

NGM (2012), 'A középosztály gyermekvállalási forradalma' [The fertility boom of the middle class.] Nemzetgazdasági Minisztérium, Budapest.

NRP (2009), Post-assessment of the NRP of Hungary in the June 2007-June 2008 period, Cseres-Gergely, Zs., October.

OECD (2002), Economic Surveys: Hungary 2002. OECD, Paris.

OECD (2007), 'Mothers in Paid Employment', in Society at a Glance 2006: OECD Social Indicators, OECD Publishing. 56-57.

OECD (2010a), OECD Economic Surveys: Hungary 2010, Paris: OECD.

OECD (2010b), Supporting labour demand, OECD position paper, July 2010.

OECD (2012a), Social Spending after the Crisis, Paris: OECD. Available at: http://www.oecd.org/els/soc/OECD2012SocialSpendingDuringTheCrisis8pages.pdf

(Retrieved December 31, 2013)

OECD (2012b), OECD Economic Surveys: Hungary 2012, Paris: OECD.

OECD, (2008), OECD Economic Surveys: Hungary 2008, OECD, Paris

OECD, (2013), OECD Economic Surveys: Hungary 2013, OECD, Paris.

Ohnsorge-Szabó, L. and Romhányi, B. (2007), 'How did we get here? Hungarian budget 20002006', Pénzügyi Szemle (Financial Review), Vol. 52. Issue 2: 243-292.

Ombudsman of Fundamental Rights (2012), Report of the Ombudsman on case AJB3025/2012. (In Hungarian.)

Orbán, V. (2012), 'Speech at the 21st EPP Congress,' 17-18 October 2012, Bucharest, Romania. Available at: http:/www.fidesz.hu/index.php?Cikk=185485 (Retrieved December 31, 2013) 
Orenstein, M.A. 2008. Privatizing Pensions: The Transnational Campaign for Social Security Reform. Oxford and Princeton: Princeton University Press.

Orosz, É. (2001), Félúton vagy tévúton? Egészségügyünk félmúltja és az egészségpolitika alternativái [Halfway or astray? The history of Hungarian healthcare and policy alternatives. Budapest, 2001. Egészséges Magyarországért Egyesület.

Palonen, E. (2009), 'Political Polarisation and Populism in Contemporary Hungary', Parliamentary Affairs, Volume 62, Issue 2: 318-334.

Palonen, Emilia, 2009: Political Polarisation and Populism in Contemporary Hungary, Parliamentary Affairs, Volume 62, Issue 2, pp. 318-334

Pik, K. (2001) A szociális munka története Magyarországon, 1817-1990. Magyarországon, 1817-1990 [The History of Social Work in Hungary, 1817-1990] Budapest: Hilscher Rezső Szociálpolitikai Egysület.

Reed, J. (2011), 'Hungary's Answer to Unemployment: Manual Labor.' CNN News Europe, 28 December 2011. (Retrieved December 31, 2013)

Róbert, Péter (ed.) (2005), Törések, hálók, hidak. Választói magatartás és politikai tagolódás Magyarországon., [Cleavages, networks and bridges. Electoral behaviour and political structure in Hungary], Budapest: DKMKA, 243-322.

Sándor, K., Sándor, P. and Vass, L. (eds) (2003), Magyarország politikai évkönyve 2003, Vol. II, Budapest: Demokrácia kutatások magyar központja, 2003. See particularly Part IV.

Scharle, Á. (2011), 'The Efficiency of Employment Rehabilitation Subsidies in Hungary.' Policy Brief, No. 1, Budapest Institute for Policy Analysis, Budapest.

Scharle, Á. and Samu, F. (2013) 'Napközbeni gyerekellátó intézmények kapacitásbővítésének célzottsága,[Targeting capacity development in daycare for children.] Report to the National Development Agency.' Working Paper (in Hungarian) August 2013.

Scheppele, K.L. (2012), 'Hungary, misunderstood?' In New York Times, 21 January 2012. Available at: http://krugman.blogs.nytimes.com/2012/01/21/hungary-misunderstood/?_r=0 (Retrieved December 31, 2013)

Semjén, A. (1996), A pénzbeli jóléti támogatások ösztönzési hatásai [Incentive effects of monetary welfare provisions], Közgazdasági Szemle, 10, 841-862.

Sik, E. 2012. 'Csúcson a kivándorlást tervezők aránya.' [Plans of out-migration on the peak.] TÁRKI, Budapest, 2012.

http://www.tarki.hu/hu/news/2012/kitekint/20120523 migracio.html (Retrieved December 31, 2013)

Sik, E. and Simonovits, B. (2010), 'Measuring discrimination in the Hungarian labour market.' 2010. In: Fazekas K., Lovász, A., Telegdy, Á. (eds), The Hungarian Labour Market, 2009. Institute of Economics, Hungarian Academy of Science, Budapest, pp. 120-134.

Simonovits, A. (2011), 'The mandatory private pension pillar in Hungary: An obituary.' In International Social Security Review, 64:3: 81-98.

Szabó, I. (2004), 'Kollektív identitásminták a politikai szocializációban' [Models of collective identity in political socialisation]., Educatio, 2004/4. 551-566. 
Szabó, I. (2013), 'Between polarization and statism - effects of the crisis on collective bargaining processes and outcomes in Hungary.' In Transfer: European Review of Labour and Research, Vol. 19. No. 2: 205-215.

Szalai, J. (1992) ‘A társadalombiztosítás érdekviszonyairól.’ In: Szociológiai Szemle 2. 27 - 43.

Szikra D. (2004) The Thorny Path to Implementation: Bismarckian social insurance in Hungary in the late 19th century. In: European Journal of Social Security, Volume 6, Nr. 3, September, 2004. Pp. 255-272.

Szikra, D. (2009), 'From Bismarck to the New Pension Orthodoxy. The Historical Development of the Pension System in Hungary.' In: Petersen, J.H. and Petersen, K. (eds), The Politics of Age. Public Pensions in a Comparative and Historical Perspective, Hamburg: Peter Lang Publishers. 41.64.

Szikra, D. (2011), 'Tradition Matters: Child Care and Primary School Education in Modern Hungary’. In: Hagemann, K., Jarausch, K. and Allemann-Ghionda, C. (eds), Child Care and Primary Education in Post-War Europe, New York and Oxford: Berghahn Books. 364-384.

Szikra, D. (2013) 'Austerity Policies and Gender Impacts in Hungary.' Working Paper. Friedrich Ebert Stiftung, Budapest Büro. http://www.fesbp.hu/publikationen.php (Retrieved December 31, 2013)

Szikra, D. (2014), 'Democracy and Welfare in Hard Times. The Social Policy of the Orbán Government since 2010. In: Journal of European Social Policy, September.

Szikra, D. and Tomka, B. (2009), 'Social Policy in East Central Europe. Major Trends in the 20st Century.' In: Cerami, A. and Vanhuysse, P. (eds), Post-Communist Welfare Pathways: Theorizing Social Policy Transformations in Central and Eastern Europe, Basingstoke: Palgrave Macmillan. 17-34.

Szívós, P. and Tóth, I. Gy. (eds) (2013), Egyenlőtlenség és polarizálódás a magyar társadalomban [Inequalities and polarization in the Hungarian Society], Tárki Monitor Jelentések 2012. TÁRKI, Budapest.

TÁRKI (2012), Társadalmi Riport [Social Report], Budapest.

The Economist (2011), 'Public works in Hungary. Do as the Chinese do,' The Economist, 30 June 2011. Available at: http://www.economist.com/blogs/easternapproaches/2011/06/public-works-hungary (Retrieved July 12th 2011)

Tóth, G. A. (ed.) (2012), Constitution for a Disunited Nation. On Hungary's 2011 Fundamental Law, Budapest - New York: Central European University Press.

UN (2013), 'Concluding Observations on the combined seventh and eighth periodic reports of Hungary adopted by the Committee at its fifty-fourth session.' Committee on the Elimination of Discrimination against Women (CEDAW), United Nations, 1 March 2013.

Vanhuysse, P. (2004) 'The pensioner booms in post-communist Hungary and Poland: political sociology perspectives', in.: International Journal of Sociology and Social Policy, 24, 1-2. 86-102

Vaughan-Whitehead, D. (1998), Paying the Price: The Wage Crisis in Central and Eastern Europe, London: Palgrave Macmillan. 
Váradi, B. (2012), 'Decision-making procedures in the national policy.' In: Fazekas and Scharle (eds), From Pensions to Public Works. Hungarian Employment Policy from 1990 to 2010, Budapest Institute and IE-HAS, Budapest. Budapest: Budapest Institute and IE-HAS, $76-88$

Vidra, Zs. (2012), 'Local governments and benefit recipients under pressure by workfare.' in:

The Consequences of Freezing Social Allowance in Rural Hungary. An Interdisciplinary Documentation. Butterfly Research. Available at: http://www.pillangokutatas.bffd.hu/findings/studies (Retrieved December 31, 2013)

Visser, J. (2006), 'Union membership statistics in 24 countries.' Monthly Labor Review, January 2006. US Bureau of Labor Statistics.

Wolff, J. (2001), The Hungarian unemployment insurance benefit system and incentives to return to work. LMU IS, Discussion Paper, No. 253.

World Bank. (2001), Hungary - Long-term Poverty, Social protection, and the Labor Market. Report, No. 20645-HU, Washington: The World Bank.

\section{FOOTNOTES}

1 Roma integration was improved substantially with the extension of compulsory schooling, infrastructure developments in rural areas and job creation for the unskilled in large stateowned firms. The extension of child care services supported working women, although they continued to do most housework. The inclusion of people with disabilities was not promoted by the Socialist regime: their choices were constrained to living on a pension (and typically in a large segregated institution, miles away from their family). or working in a sheltered job.

2 Balla et al. (2008) show that the preference for benefits over wage subsidies and active labour market measures to facilitate the reemployment of low-productivity workers was an important factor in the persistence of high unemployment.

3 Bohle and Greskovits (2012) show a similar pattern in post-transition welfare regimes in the Visegrad countries and label it 'embedded neoliberalism'.

4 Most importantly, local government was defined at the settlement level, resulting in a multitude of very small municipalities. The initially considerable autonomy of the local level was gradually stifled by central regulation and repeated reductions in locally used tax revenues, while professional supervision as well as redistribution towards poor areas remained limited.

5 In response, the unions went on strike, the minister for welfare resigned and MPs of both the ruling coalition and the opposition parties raised their voice against the welfare cuts, but the austerity package was nevertheless passed amid the looming financial crisis (Antal 2000; Kelen 1996).

6 Before the transition, the only trade union (Szakszervezetek Országos Tanácsa [SZOT], the National Council of Unions) was formally responsible for running the whole social insurance system. Its role was reduced to implementing decisions made by the Politburo of the Communist Party, however (Szikra 2009).

7 Social services had no separate administration (but were run within the health care system) until the mid-1980s, when the first family help centres were established. Psychiatric patients (including alcoholics and drug addicts) were often treated in a coercive manner, out of sight of society, especially until the mid-1980s (see Pik 2004; Bugarszki 2004). 
8 For example, while 20 per cent of nominees were women in the 2002 national elections, only 9 per cent got elected; 14 per cent of all mayors were women following the local government elections and their proportion was even lower in larger settlements (MSAL 2003).

9 On the process and causes of political polarisation see Palonen (2009) and Körösényi (2012).

10 There were in fact two corrections to public sector pay in 2002: the outgoing Conservative government increased wages by 17 per cent in real terms just before the elections in May, and the incoming Socialist-Liberal coalition gave a further rise of 29 per cent in September, as promised in their election campaign (Altwicker-Hámori and Köllö 2013).

11 The first freely elected government was formed by the Conservative MDF (Forum of Hungarian Democrats) ruling between 1990 and 1994. They were replaced by a SocialistLiberal coalition (1994-1998). The Conservatives regained power in 1998, in a coalition led by the originally liberal party FIDESZ (Young Democrats' Alliance-Hungarian Civic Union). The Socialist Party took over in 2002 and was re-elected in 2006, in coalition with a small liberal party, SZDSZ (Free Democrats). who left the coalition in 2008.

12 As already mentioned, these included a substantial rise in the minimum wage, tightening access to unemployment benefits and the introduction of tax credits for low income families with children.

13 The Socialist-Liberal coalition (2002-2006) abolished tax credits for families, doubled universally available family allowance and introduced a minimum income scheme for unemployed households (Inglot et al. 2012).

14 In a telling initiative, they attempted to introduce 'family mainstreaming' on the EU agenda under the Hungarian Presidency in 2011. See Inglot et al. 2012 and Juhász 2014.

15 The new government did not formally renounce the National Strategy for the Promotion of Gender Equality 2010-2021 drafted by the previous, Socialist government, but has not made a genuine effort to implement it.

16 It was this unit, however, that launched a programme on the 'fertility boom among the middle class' (NGM 2012).

17 According to Directive 2010/18/EU at least four months of parental leave should be granted, of which a division is recommended whereby 'each parent retains at least one of the four months of leave.'

18 The role of short-time working schemes (financed by the central budget or the ESF) aimed at increasing or preserving labour demand was moderate in Hungary: slightly less than 1 per cent of workers took part in such a programme in 2009. However, their effectiveness was below average: the OECD estimated that around 0.1 per cent of all permanent jobs could be saved in this way, while in the best performing country, Belgium, the programme contributed to the preservation of 1.3 per cent of jobs with an almost 6 per cent participation rate (OECD 2010a).

19 The slow recovery of credit markets also plays a role. Banks are struggling to consolidate bad debts accumulated during the late 2000s (and especially the unprecedented expansion of foreign currency loans) and to keep their clientele despite rising transaction costs (entailed by new taxes).

20 The maximum duration of unemployment insurance was cut to 12 months in Greece, 11 months in Portugal and 24 months in Denmark. See Missoc Database 2013. The gradual cuts in the German Hartz reforms kept the maximum duration at 24 months. For more detail, see chapters by Bosch (Germany), Karamessini (Greece) and Simonazzi (Italy) in this volume.

21 The Social Act of 1993 establishing the new legal framework for the social assistance system left earlier provisions largely unchanged but they took on a more general function as 
unemployment increased. The obligation to cooperate with the job centre or family centre was extended to social assistance in 1997.

22 To correct the negative effects of the 1999 amendment', the government reintroduced the second phase of unemployment insurance, with special, more favourable conditions for those with fewer than five years before retirement age (Frey 2003: 176).

23 Those getting reemployed before exhausting benefit would receive 50 per cent of the benefit amount which would have been due for the rest of the benefit duration.

24 Both the floor and the ceiling of unemployment insurance were raised, which compensated for the drop in the replacement rate from 65 to 60 per cent.

25 For over 20 years, unemployment assistance was called 'rendszeres szociális segély', then renamed 'rendelkezésre állási támogatás' in January 2009, 'bérpótló juttatás' in January 2011 and 'foglalkoztatást helyettesítő támogatás' in September 2011.

26 This pattern resembles current practice in unregistered casual employment and daylaborers in agriculture, rather than regular labour contracts.

27 A further 8.3 per cent worked six hours a day and only about the quarter of workers full time. See Koltai and Kulinyi 2013, 46.

28 The new rules are extremely complicated and intransparent: the exclusion may apply during 14, 12, 3 or 2 months. While most people are excluded for a year, some may fare better, especially if they were formerly receiving some type of care allowance.

29 This is clearly unrealistic even with an all-encompassing public works programme. The total labour force was 3,811,900 out of the total population of 9.9 million in 2011. See Bálint 2013, Table 4.1. page 336.

30 Gyula Gömbös was the founder of an anti-Semitic party in the 1920s. By the 1930s he became the leader of the Conservative "Party of National Union" through which he aimed at building up authoritarian rule by weakening Parliamentary democracy. However, his early death prevented him from fulfilling his aims. The original name of FIDESZ'S employment strategy was exactly the same as Gömbös's but after this was raised in the media they changed the name from 'national' to 'Hungarian' Work Plan. For details see Szikra 2011 and Amerikai Népszava 2011.

31 Hungarian Roma comprise about 5-10 per cent of the total population and an increasing share of the poor and the long-term unemployed (estimated around 30 per cent, Szívós and Tóth 2013.

32 The 3,000 mayors who are elected directly in each village, town and city may hold a seat in Parliament as well, and many of them do, which clearly increases the power of their lobby.

33 Established in 2003, Jobbik ('The Movement for a Better Hungary'). burst onto the political scene by winning three of the 22 Hungarian seats at the EU elections in 2009.

34 The research was conducted in the course of 2012 among employers of public workers via an online questionnaire and interviews. It covered the employers of altogether about 20 per cent of all public workers in 2011 and 2012. Other frequently mentioned merits included the 'exclusion of those who do not want to work' and the 'decrease in the number of unemployed'. Koltai and Kulinyi 2012:56.

35 Roma women turned to the Ombudsman and claimed that they were excluded from the public works programme due to their 'wearing traditional costumes' during work in Gyöngyös, a small town in the North-East. Claim Nr AJB-4162/2012. In. Az alapvető jogok biztosának jelentése. p. 2.

36 For instance, Roma were called upon for public works by the mayor of a small village one day before the actual work has started and those who did not react immediately were excluded 
from the social assistance system as a whole. Available at: http://jogtalanul.blog.hu/2012/03/20/mintha_rendkivuli_allapot_lenne (Accessed 12 May 2013).

37 Gainful employment was ranked the lowest among the possible 'merits' of public works, while financial gains for the local government, and the maintainence of social networks were both ranked higher.

38 The maximum benefit duration is 5 months (second lowest in the EU) in the Czech Republic and Cyprus and 6 months in the United States and the United Kingdom.

39 For Hungary, estimates by Galasi (1996) provide evidence that a larger benefit amount is associated with greater intensity in searching for a job, at least in the case of men.

40 The early repayment scheme in 2011 favoured well-off borrowers, who were able to pay off their mortgages denominated in foreign currency at a preferential exchange rate. The scheme cost banks an estimated 0.9 per cent of GDP, while it made a limited contribution to tackling the problem of non-performing loans (OECD 2013). 